\title{
Fauna associated with shallow-water methane seeps in the Laptev Sea
}

\author{
Andrey A Vedenin ${ }^{\text {Corresp., } 1}$, Valentin N Kokarev ${ }^{2,3}$, Margarita V Chikina ${ }^{3}$, Alexander B Basin ${ }^{3}$, Sergey V Galkin ${ }^{4}$, \\ Andrey V Gebruk ${ }^{4}$ \\ ${ }^{1}$ Laboratory of plankton communities structure and dynamics, P.P. Shirshov Institute of Oceanology, Moscow, Russia \\ 2 Faculty of Biosciences and Aquaculture, Nord University, Bodø, Norway \\ 3 Laboratory of Ecology of Coastal Bottom Communities, P.P. Shirshov Institute of Oceanology, Moscow, Russia \\ 4 Laboratory of Ocean Bottom Fauna, P.P. Shirshov Institute of Oceanology, Moscow, Russia \\ Corresponding Author: Andrey A Vedenin \\ Email address: urasterias@gmail.com
}

Background. Methane seeps support unique benthic ecosystems in the deep sea existing due to chemosynthetic organic matter. In contrast, in shallow waters there is little or no effect of methane seeps on macrofauna. In the present study we focused on the recently described methane discharge area at the northern Laptev Sea shelf. The aim of this work was to describe the shallow-water methane seep macrofauna and to understand whether there are differences in macrobenthic community structure between the methane seep and background areas.

Methods. Samples of macrofauna were taken during three expeditions of RV Akademik Mstislav Keldysh in 2015, 2017 and 2018 using $0.1 \mathrm{~m}^{2}$ grabs and the Sigsbee trawl. 21 grabs and two trawls in total were taken at two methane seep sites named Oden and C15, located at depths of 60-70 m. For control, three $0.1 \mathrm{~m}^{2}$ grabs were taken in area without methane seepage.

Results. The abundance of macrofauna was higher at methane seep stations compared to non-seep sites. Cluster analysis revealed five station groups corresponding to control area, Oden site and C15 site (the latter represented by three groups). Taxa responsible for differences among the station groups were mostly widespread Arctic species that were more abundant in samples from methane seep sites.

However, high densities of symbiotrophic siboglinids Oligobrachia sp. were found exclusively at methane seep stations. In addition, several species possibly new to science were found at several methane seep stations, including the gastropod Frigidalvania sp. and the polychaete Ophryotrocha sp. The fauna at control stations was represented only by well-known and widespread Arctic taxa. Higher habitat heterogeneity of the C15 site compared to Oden was indicated by the higher number of station groups revealed by cluster analysis and higher species richness in C15 trawl sample. The development of the described communities at the shallow-water methane seeps can be related to pronounced oligotrophic environment on the northern Siberian shelf. 
1 Fauna associated with shallow-water methane seeps in the Laptev Sea

2

3

4

5

6

8

9

10

11

12

13

14

Andrey A. Vedenin ${ }^{1}$, Valentin N. Kokarev ${ }^{1,2}$, Margarita V. Chikina ${ }^{1}$, Alexander B. Basin ${ }^{1}$, Sergey V. Galkin ${ }^{1}$, Andrey V. Gebruk ${ }^{1}$

1 - P.P. Shirshov Institute of Oceanology, Moscow, Russia

2 - Nord University, Faculty of Biosciences and Aquaculture, Bodø, Norway

Corresponding Author:

Andrey A. Vedenin ${ }^{1}$

Nahimovskiy Prospekt 36, Moscow, 117997, Moscow, Russia

Email address: urasterias@gmail.com

\section{Abstract}

Background. Methane seeps support unique benthic ecosystems in the deep sea existing due to chemosynthetic organic matter. In contrast, in shallow waters there is little or no effect of methane seeps on macrofauna. In the present study we focused on the recently described methane discharge area at the northern Laptev Sea shelf. The aim of this work was to describe the shallow-water methane seep macrofauna and to understand whether there are differences in macrobenthic community structure between the methane seep and background areas.

Methods. Samples of macrofauna were taken during three expeditions of RV Akademik Mstislav Keldysh in 2015, 2017 and 2018 using $0.1 \mathrm{~m}^{2}$ grabs and the Sigsbee trawl. 21 grabs and two trawls in total were taken at two methane seep sites named Oden and C15, located at depths of 60-70 m. For control, three $0.1 \mathrm{~m}^{2}$ grabs were taken in area without methane seepage.

Results. The abundance of macrofauna was higher at methane seep stations compared to nonseep sites. Cluster analysis revealed five station groups corresponding to control area, Oden site and $C 15$ site (the latter represented by three groups). Taxa responsible for differences among the station groups were mostly widespread Arctic species that were more abundant in samples from methane seep sites. However, high densities of symbiotrophic siboglinids Oligobrachia sp. were found exclusively at methane seep stations. In addition, several species possibly new to science were found at several methane seep stations, including the gastropod Frigidalvania sp. and the polychaete Ophryotrocha sp. The fauna at control stations was represented only by well-known and widespread Arctic taxa. Higher habitat heterogeneity of the C15 site compared to Oden was indicated by the higher number of station groups revealed by cluster analysis and higher species richness in $C 15$ trawl sample. The development of the described communities at the shallowwater methane seeps can be related to pronounced oligotrophic environment on the northern Siberian shelf. 
39

40

41

42

\section{Introduction}

Methane gas seeping from the seafloor, similar to hydrothermal vents, can support the conditions for unique fauna largely independent of photosynthetic primary production (Van Dover, 2000; Levin, 2005; Dando, 2010). Distinct faunal response at methane seeps (also known as "cold seeps") associated with increase of abundance and biomass and presence of unique taxa absent in background areas has been described from many areas of the ocean (Gebruk, 2002; Baker \& German, 2004; Levin, 2005; Sommer et al., 2009). Taxa restricted to methane seeps either develop symbiotic relationships with methanotrophic or sulphide-oxidizing bacteria or feed directly on benthic or suspended bacterial matter. In addition, secondary consumers such as predators feeding exclusively on symbiotrophic taxa and grazers may be present (Dando, 2010).

In the Arctic Ocean, several methane seep ecosystems have been discovered and investigated. The most studied include the Håkon Mosby mud volcano (HMMV) in the Norwegian Sea (Gebruk et al., 2003) and several sites around Svalbard and at Vestnesa Ridge (Åström et al., 2016; Åström et al., 2018). Other described cold seeps include the LofotenVesterålen continental margin area (Sen et al., 2019a) and mud volcanoes in the Beaufort Sea (Paull et al., 2015). The cold seeps inhabited by chemosymbiotic benthic taxa are mostly located below the photic zone (depth $>200 \mathrm{~m}$ both around Svalbard and at HMVV) (Gebruk et al., 2003; Åström et al., 2016). At the same time, macrobenthic communities from areas with extensive methane discharge located at shallow depths (e.g. in the Norwegian and White Seas at depths $<100 \mathrm{~m}$ ) show no or minor response in terms of chemosymbiotic communities development (Savvichev et al., 2004; Levin, 2005). However, at the shallow-water cold seeps certain changes in abundance/biomass of the common macrofaunal taxa are often observed, caused by enhanced vertical mixing, productivity and additional hard substrata (carbonate crusts) due to extensive methane discharge (Jensen et al., 1992; Sahling et al., 2003; Pohlman et al., 2017). In general, a depth boundary is observed between shallow-water cold seeps and their "deep-sea" counterparts at approximately $200 \mathrm{~m}$ (Tarasov et al., 2005; Dando, 2010). One of possible reasons for this boundary is the origin of organic matter: at depths $<200 \mathrm{~m}$ photosynthetic organic matter is more available for benthic consumers due to stronger bentho-pelagic coupling (Levin, 2006; Dando, 2010), while at greater depth the amount of photosynthetic organic matter decreases and 
68

69

chemosynthesis starts to play a significant role for local organic matter production. Therefore, despite the presence of methane and sulfides (unfavorable for most organisms due to toxicity), unique and diverse ecosystems can develop at deep-sea cold seeps (Powell et al., 1986; Dando et al., 1993; Dando, 2010).

Fauna associated with cold seeps in the Arctic includes symbiotrophic siboglinid polychaetes and thyasirid bivalves, but mainly consists of widespread Arctic species not restricted to methane seeps (Gebruk et al., 2003; Åström et al., 2016; Åström, Oliver \& Carroll, 2017). Arctic cold seep assemblages are characterized by the dominance of frenulate siboglinid worms, while large chemosymbiotrophic methane seep taxa (vestimentiferan worms, bathymodioline and vesicomyid bivalves) are absent (Sen et al. 2018). One of the common effects of Arctic methane seeps on macrobenthic communities is an increased abundance and biomass of regular allochthonous taxa compared to the background (e.g. Rybakova et al., 2013; Åström et al., 2016), although species richness at cold seeps is usually not higher than in the background (in terms of macrofauna) all over the world (Levin, 2005; Dando, 2010). However, recent results obtained from the southwestern Barents Sea showed increased taxonomic richness within the seepage sites (Sen et al., 2019b). Outside the Arctic similar species richness patterns were reported from the Gulf of Mexico (Cordes et al., 2010) and Argentina (Bravo et al., 2018).

In the Siberian Arctic, areas of intense methane discharge (methane seeps) were discovered on the outer shelf of the Laptev Sea in 2008 (Yusupov et al. 2010). Further research revealed numerous gas flares in the northern Laptev Sea shelf (Lobkovsky et al., 2015; Shakhova et al. 2015). Within this area specific microbial communities based on methane oxidation were discovered (Savvichev et al. 2018). Baranov et al. (2020) suggested that methane seeps occur through the fault system belonging to the Laptev Sea Rift system and the Khatanga-Lomonosov Fracture Zone located between the Eurasian and North American Tectonic Plates. The faults may conduct the gas from reservoirs deep in the sediment below the caprock formed by permafrost and gas hydrates (Shakhova et al. 2015; Thornton et al. 2016; Baranov et al., 2020). Within the seeping area, multiple bacterial mats and occasional methane bubbles and carbonate crusts were observed (Baranov et al., 2020).

The methane associated fauna was registered on the Laptev Sea shelf and slope much earlier. During expeditions of RV Polarstern in 1993 and 1995 five species of siboglinids were 
98 found in this area in the depth range 50-2000 m (Sirenko et al., 2004), which is more species 99 than anywhere else in the high Arctic (Buzhinskaja, 2010).

100 We examined benthic communities associated with methane seeps in the Laptev Sea at two 101 sites: $C 15$, centred around $76^{\circ} 47.4^{\prime} \mathrm{N}$ and $125^{\circ} 49.5^{\prime} \mathrm{E}$ with depths $70-73 \mathrm{~m}$ and Oden, centred 102 around $76.894^{\circ} \mathrm{N}$ and $127.798^{\circ} \mathrm{E}$, with depths $63-67 \mathrm{~m}$. Preliminary description of benthic 103 megafauna based on video recordings obtained by ROV was published by Baranov et al. (2020).

104 The aim of this study is to describe the biological peculiarities of the methane seep macrofauna 105 based on grab and trawl samples and to reveal differences in either integral community 106 characteristics or distribution of certain species between the methane seep and background areas. 107 We hypothesized that the seep sites are different from the non-seep in terms of macrofauna 108 (general community characteristics and certain species distribution).

\section{Materials \& Methods} Samples of macrofauna were taken during three expeditions of RV Akademik Mstislav Keldysh in 2015 (AMK-63), 2017 (AMK-69) and 2018 (AMK-72) on the northern Laptev Sea shelf, in

113 the area of active methane discharge. The gears used for sampling included the Okean (in 2015) and van Veen (in 2017-2018) grabs (0.1 $\mathrm{m}^{2}$ sampling area) and the Sigsbee trawl (2 m frame width) (Eleftheriou \& McIntyre, 2005). 21 grab and two trawl stations were performed in total at three sites: on two methane seep fields (12 grabs and one trawl at C15, 70.6-73.0 m depth, and six grabs and one trawl at Oden, 63.0-63.1 m depth) and at the control site with no methane seeping (3 grabs, 69.6-69.7 $\mathrm{m}$ depth) (Fig. 1). A single trawl was taken at each seep site to minimize the possible ecosystem damage from this gear. In 2015 three seep stations were performed at sites where gas bubbling (gas flares) was visible on echo-sounder. Three more grabs were taken $\sim 200 \mathrm{~m}$ away from the nearest gas flare to catch background community. In 2017 and 2018 station selection was based largely on the previously mapped methane flares (Baranov et al., 2020). All the 2017 and 2018 grabs were taken above the gas flares (Fig. 1). Station data with coordinates and depths are shown in Table 1. For additional information on methane seep fields see Flint et al. (2018) and Baranov et al. (2020).

Table 1. Data on stations used in the present study. For trawl stations coordinates and depth of start and end are given. 
Fig. 1. Study area.

Enlarged maps show sampling sites and corresponding stations. Detailed bathymetry is only available for C15 and Oden sites; white circles indicate previously recorded gas flares (Baranov et al., 2020). Dotted line at Oden site enclosed map shows the approximate perimeter of seeping area.

Sediment from grab samples was washed by hand through the $0.5 \mathrm{~mm}$ mesh size sieve, and fixed with buffered $4 \%$ formalin solution afterwards. Two grab samples from the expedition in 2018 (Stat. 5947-3 at C15 and 5953-2 at Oden site) were fixed with 96\% ethanol. A 10-litre subsample of sediment taken from each trawl catch was washed through the $1 \mathrm{~mm}$ mesh size sieve and then fixed with neutralized $4 \%$ formalin. The material obtained was analyzed in the laboratory; all macrofaunal organisms were identified to the lowest possible taxonomical level and counted. Species from grab samples were weighed (wet weight, all specimens of each species at a time). Mollusks were weighed with shells, polychaetes with calcareous (spirorbids) or mucous tubes (Spiochaetopterus typicus and siboglinids) were weighed with tubes. Density and biomass were calculated per square meter for grab samples. Dominant species were distinguished by biomass. For trawl samples we calculated the contribution (in \%) of each species to abundance. Biomass was not measured for trawl samples due to poor state of preservation. For ethanol fixed samples from Stat. 5947-3 and 5053-2, the biomass loss was corrected using taxa-specific coefficients after Brotskaya \& Zenkevich (1939).

For grab samples total abundance, biomass, species richness (species number), Pielou evenness, Hurlbert rarefaction index and Shannon-Wiener diversity index $\left(\mathrm{H}^{\prime} \mathrm{ln}\right)$ were calculated to get integral community characteristics. Abundance and biomass data from grab samples were standardized and square root transformed to increase the role of rare taxa and to reduce the impact of highly abundant taxa. The similarity among grab samples was estimated using the quantitative index of Bray-Curtis. Clusters were built based on similarity matrices using the unconstrained tree routine (UNCTREE); results were verified by SIMPROF to distinguish different station groups with significant differences in species composition. The results from cluster analysis were verified by non-metric multidimensional scaling (n-MDS). Clusters revealed by these methods were defined as separate station groups in terms of quantitative taxonomical similarity. Shade plots were built to visualize the species abundance and biomass differences between the stations and species in clusters. The Kruskal-Wallis test was used to verify differences in certain taxa distribution among station groups, followed by Dunn's post-hoc 
163 test (with Holm adjustment for multiple comparisons). Species-individuals accumulation curves 164 were plotted for each station group (McCune, Grace \& Urban, 2002; Clarke \& Gorley, 2015; R 165 Development Core Team, 2020).

166 For all species present in any station group, an algorithm estimating the likelihood of 167 accidental catch was applied. If a uniform distribution of species between two sampling efforts A and B is assumed, the probability of species absence at each station of B-sampling would be (1$\left.P_{\mathrm{A}}\right)^{\mathrm{N}(\mathrm{B})}$, where $\mathrm{N}(\mathrm{B})$ is the number of stations in $\mathrm{B}$-sampling and $P_{\mathrm{A}}$ is the species occurrence (the proportion of stations where the species was present) in A-sampling. Using this equation, the likelihood of accidental absence of any species in either station group can be estimated. The number of grabs required for species catch in B-sampling can be calculated by the equation: $n=$ $\lg (\alpha) \lg \left(1-P_{\mathrm{A}}\right)^{-1}$, where $\alpha$ is the likelihood of species finding in B-sampling taken as 0.99 (Azovsky, 2018; Vedenin et al., 2019).

For trawl samples, the species rank distributions were plotted. Species richness, Pielou evenness, Hurlbert rarefaction index and Shannon-Wiener diversity index were calculated using the taxa-percentage values. Differences between trawl catches were estimated by similarity percentage routine (SIMPER).

Statistical analyses were performed in Primer V6, V7, Past 3.0 and R V3.6.1 with R 180 package Dunn.test V1.3.5 software (Clarke \& Warwick, 2001; Hammer, 2013; Clarke \& Gorley, 2015; R Development Core Team, 2020).

\section{Results}

A total of 289 taxa of benthic macrofauna were identified in grab and trawl samples. In grab samples, density varied from 580 ind. $\mathrm{m}^{-2}$ (St. 5624-3, Control site) to 9880 ind. $\mathrm{m}^{-2}$ (St. seep-3, C15 site). Biomass ranged from $16.28 \mathrm{~g} \mathrm{ww} \mathrm{m}^{-2}$ (St. seep-1, C15 site) to $405.79 \mathrm{~g} \mathrm{ww} \mathrm{m}^{-2}$ (St. 5623-3, Oden site). The list of all identified taxa from trawl and grab samples, with values of abundance and biomass is given in the Supplementary 1. 


\section{Grab samples}

191 Unconstrained tree with SIMPROF analysis revealed five significantly distinct groups of

192

193

194

195

196

197

198

199

200

201

202

203

204

205

206

207

208

209

210

211

212

213

214

215

216

217

218

219

220

221

222 samples (Fig. 2). The UNCTREE parameters are shown in Supplementary 2. The groups partly corresponded with the station locations and presence/absence of methane seeps (Control, C15 and Oden sites). To avoid a mix-up between the station groups and seeping sites hereinafter the corresponding names are used with either -station group or -site ending.

Fig. 2. UNCTREE analysis with SIMPROF results (A) and non-metric multidimensional scaling plot (B) of grab stations using the Bray-Curtis similarity index.

Square root transformed biomass data are used. Samples and knots that were not significantly different at $p<0.05$ are connected with red dashed lines. Green lines indicate SIMPROF groups.

\section{Characteristics of station groups}

At the Control station group (Fig. 1), the bivalve Portlandia arctica comprised most of the biomass at all three stations, followed by the starfish Ctenodiscus crispatus and the bivalve Macoma calcarea. Due to the low number of samples, the species-individuals accumulation curve did not reach the saturation point (Fig. 3). Control station group had in comparison to the other groups from $C 15$ and Oden seep sites the lowest density and species richness, whereas the evenness was the highest (Fig. 4).

The C15-seep a station group included five stations, all within the $C 15$ seep site. In this group, biomass and diversity values were intermediate among other station groups. Dominant species in this group were the bivalve Nuculana pernula, the siboglinid Oligobrachia sp. and the polychaete Cistenides hyperborea. Species-individuals accumulation curve in this group reached saturation due to the largest number of samples (Fig. 3).

The $C 15$-seep $b$ station group consisted of only two stations from C15 site. This group demonstrated the highest abundance values and low biomass among all groups. Dominant species included small polychaetes Cossura longocirrata, Micronephthys minuta and Ophryotrocha sp. (Fig. 4, Supplementary 1).

The Oden station group included six stations, all located within the Oden seep site. Values of biomass, species richness and diversity indices in this group were the highest among all station groups (Fig. 4). The main dominant species were the siboglinid Oligobrachia sp. and the polychaetes Myriochele heeri and Nephtys ciliata. 
Fig. 3. The species-individuals accumulation curves for the station groups.

Colors are the same as in Figure 2.

Fig. 4. Univariative characteristics of identified clusters expressed in standard box plots.

Values of total density, biomass, species richness, Pielou evenness, Hurlbert rarefaction index and Shannon-Wiener index are shown. Each graph contains interquartile ranges (colored boxes), mean values (horizontal line inside each box) and minimum and maximum values (lines outside the boxes). Exact values of these characteristics are shown in Supplementary 3. Colors are the same as in Figure 2 and 3.

The last group C15 background contained five stations taken within the C15 site. Taxonomical composition at these stations was similar to that in the Control group, with the bivalve Portlandia arctica being the dominant species. Bivalves Yoldiella lenticula and Y. solidula were subdominant. In this station group, the biomass values were the lowest, other general community characteristics were intermediate (Fig. 4). Similar to the Control group, C15 background did not reach the saturation point at species-individuals accumulation plot (Fig. 3).

\section{Comparison of seep and non-seep station groups}

General community characteristics in the station groups appeared different in abundance, biomass and diversity (Fig. 4, Supplementary 3). The abundance of several taxa varied significantly among five station groups (Control, C15 background, C15 seep a, C15 seep b and Oden) (Fig. 5). The Kruskal-Wallis test showed that differences in abundance of at least ten species are statistically reliable (Table 2). Statistics of the Dunn's test are shown in Supplementary 4. The seep sites were characterized by higher densities of the polychaetes Tharyx sp. and Cistenides hyperborea and the ophiuroid Ophiocten sericeum. On the contrary, the bivalve Portlandia arctica was markedly more abundant in Control and, to a lesser extent, in C15 background station groups (Fig. 5). Notable were extreme densities of small polychaetes at some seep stations, including Cossura longocirrata and Ophtyotrocha sp. (Fig. 5A) at C15 seep $b$.

Fig. 5. Shade plot of species square root transformed abundance (A) and biomass (B) at stations arranged by clusters.

The species list is reduced to 20 most important taxa. Order of stations and colors the same as in Figure 2. Taxa grouped in clusters using UPGMA algorithm based on index of association. 
Certain species present at some methane seep sites were completely absent at the non-seep

259

260

261

262

263

264

265

266

267

268

269

270

271

272

273

274

275

276

277

278

279

280

281

282

283

284

285

286

287

288

289

290

291

292 sites (Fig. 5). Among them, at least five species (the polychaetes Spiochaetopterus typicus and Nephtys ciliata, the siboglinid Oligobrachia sp., the bivalve Axinopsida orbiculata and the amphipod Pleusymtes pulchellus) were present only at C15 and Oden sites not randomly. At least one species, the undescribed gastropod Frigidalvania sp., was present only in Oden station group and absent in other station groups not randomly (Table 3). The estimated number of grabs required to catch the latter species was slightly lower than the number of grabs taken.

Table 2. Results of the Kruskal-Wallis and Dunn's post-hoc tests for taxa with different abundance values in five station groups. Mean abundance in each station group is shown (ind. $\mathrm{m}^{-2}$ ). Taxa are arranged according to $p$-value. Pairs in Dunn's pairwise comparisons column indicate significant comparisons (Dunn's $p<\alpha / 2=0.025$ ).

1 - Control group; 2 - C15 background group; 3 - Oden group; 4 - C15-seep a group; 5 - C15-seep-b group.

Table 3. Species occurrence, likelihood of not finding a species, number of grabs taken and number of grabs required for finding a species calculated for the species present only at seep sites and only at $C 15$ site.

\section{Trawl samples}

The overall Bray-Curtis similarity between the two trawls was $65.6 \%$. Species ranking graphs showed high level of dominance by abundance for both trawl stations (Fig. 6). The dominant species in both trawls was the ophiuroid Ophiocten sericeum: $37 \%$ of the total abundance at $C 15$ and $46 \%$ at Oden. The second most abundant species at C15 was the gastropod Frigidalvania sp. $(12 \%)$ and at Oden the bivalve Yoldiella solidula (11\%). Ten most abundant species accounted for $>70 \%$ of the total abundance in both trawls (Fig. 6).

Fig. 6. Species ranking for $C 15$ and Oden trawl samples.

The most numerous species are indicated. $\mathrm{X}$-axis is logarithmic.

Species richness, Pielou evenness, Hurlbert rarefaction for 100 individuals and ShannonWiener index are shown in Table 4. The evenness and ES (100) was higher in the Oden-trawl than in the C15-trawl, similar to results based on grab samples. However, the species richness (as 
293 well as the total amount of individuals) in the C15-trawl was higher than in the Oden-trawl 294 (Table 4, Supplementary 1).

295 Species responsible for taxonomical difference between the two trawl samples are shown 296 in Table 5. Most notable is a high abundance of the gastropod Frigidalvania sp. at C15. At Oden 297 Frigidalvania sp. was also present, but in much smaller densities (only $2.3 \%$ of the total 298 abundance). In addition, C15-sample differs from Oden by high numbers of various filter-feeders 299 including 6 species of sponges (with Craniella polyura being most numerous), at least 6 species 300 of cnidarians, 17 species of bryozoans and 3 species of tunicates (Table 6).

At C15 trawl sample, a large piece of carbonate crust was found. Cavities of its pores were inhabited by numerous polychaetes, also recognized from the soft sediments around the seepage

303 304 305 area (e.g. members of families Nephthyidae, Nereididae, Oweniidae and Terebellidae, see Supplementary 1), and by several filter-feeders (Hydrozoa).

Table 4. Species richness, Pielou evenness, Hurlbert rarefaction for 100 individuals and Shannon-Wiener index calculated for trawl samples.

Table 5. Similarity percentage routine for trawl samples. Species with contribution $>0.5 \%$ are shown. Species more abundant at $C 15$ are marked with bold.

Table 6. List of filter-feeding taxa found in trawl samples.

\section{Comparison of C15 and Oden sites}

All gears showed significant differences between the $C 15$ and Oden sites expressed in different taxonomical composition and quantitative characteristics. The Bray-Curtis similarity between the sites according to the grab samples and trawl samples was 26.2 and 65.6, respectively. The main differences in species composition included the high abundance of the sponge Craniella polyura and the gastropod Frigidalvania sp. at C15 site and higher numbers of the ophiuroid Ophiocten sericeum at Oden site.

The grab samples indicated a high level of heterogeneity in benthic fauna distribution. Some species formed patches, for example Oligobrachia sp., Cossura longocirrata and Ophryotrocha sp., being extremely numerous at some and moderate in abundance at the neighboring grab stations. There were also species with rather uniform distribution based on combined data, for example Ophiocten sericeum. According to the cluster analysis, the C15 site 
326 is more heterogenic forming at least three different species complexes within its area (Fig. 2).

327 Dissimilarities within the C15 and Oden sites were 64.7 and 26, respectively (Supplementary 2).

328 Dominant species were different in grab and trawl samples. The dominant species in trawls

329 at the two methane seep sites was the ophiuroid Ophiocten sericeum, whereas for grab samples,

330 the siboglinid Oligobrachia sp., the bivalve Nuculana pernula and the polychaete Myriochele

331 heeri were the most abundant.

332

333

Discussion

334

335

336

337

338

339

340

341

342

343

344

345

346

347

348

349

350

351

352

353

354

\section{Integral community parameters: methane seep vs. non-seep}

The abundance of macrofauna was higher at the seep stations compared to the background, based on the grab samples. In addition, at Oden seep site the biomass was higher compared to non-seep sites. High abundance and biomass has been reported from both hydrothermal vents and cold seeps all over the world, compared to the surrounding areas (Levin, 2005; Dando, 2010). In the Arctic, a twofold increase of biomass compared to control sites was observed at cold seeps south off Svalbard (mean values of 20.7 vs. $9.8 \mathrm{~g} \mathrm{ww} \mathrm{m}^{-2}$ ), the abundance increase was less prominent (770 vs. 590 ind. $\mathrm{m}^{-2}$ ) (Åström, 2016). At the Vestnesa Ridge the infaunal abundance and biomass was almost five times higher compared to a nearby control area (497 vs. 140 ind. $\mathrm{m}^{-2}$ and 2.97 vs. $0.48 \mathrm{~g} \mathrm{ww} \mathrm{m}^{-2}$, respectively) (Åström et al., 2018). For the Håkon Mosby mud volcano, which is very deep compared to the Laptev Sea cold seeps $(1250$ vs. $70 \mathrm{~m}$, respectively), though similar in species composition (Oligobrachia fields near the seepage zones and Ophiocten-dominated background community) the comparison of abundance and biomass with the background is not available. In our study, the abundance at the methane seep sites C15 and Oden was more than four times higher than at the control. However, differences in biomass although pronounced were not statistically significant. Increased biomass at seep habitats is commonly explained by enhanced organic matter supply and habitat heterogeneity (Gebruk et al. 2003; Sen et al. 2018).

Pielou's evenness was distinctly higher at the Control and C15 background station groups, which reflects the increased dominance of certain species at seep stations compared to non-seep. Many authors reported high abundance and biomass values of one to few dominant 
355 species at various cold seeps (Gebruk et al. 2003; Åström, 2016; Åström et al., 2018). This can

356 be caused by conditions less favorable for some background species (due to the presence of 357 methane and sulphides and lower oxygen level), but more favorable for symbiotrophs or grazers 358 (Powell et al., 1986; Dando et al., 1993; Dando, 2010).

359 The cold seeps all over the world oceans usually demonstrate lower diversity values 360 (ES(100) and Shannon-Wiener index) compared to the background areas (summarized by Levin, 361 2005). However, species list from grab and trawl samples showed high ES(100) and Shannon362 Wiener index values although only two trawls were sampled. Studies on the Siberian shelf using 363 the same gear under the same conditions obtained less than 150 species per trawl (Galkin \& 364 Vedenin, 2015; Vedenin, Galkin \& Kozlovsky, 2015), while a total of 203 species were found in 365 a single $C 15$ sample. The unusually high diversity may reflect a higher amount of microniches 366 within the $C 15$ site. This is indirectly confirmed by lower similarity values observed between all 367 C15 grab samples. Higher habitat heterogeneity at seep sites can increase the overall diversity of 368 benthic fauna (Bergquist et al., 2003; Gebruk et al. 2003; Levin, 2005; Menot et al., 2010; 369 Åström et al., 2018). The scale of heterogeneity is hard to assess, but based on stations coordinates and the fact that stations 5947-1 and 5947-2 from C15-site were grouped in C15 background (though planned as seep stations near the gas flares), while station 5947-2 was grouped as C15-seep a, we can assume that the scale is less than $5 \mathrm{~m}$ (distance between these stations) (Fig. 1; Table 1).

In addition, the diversity values (ES(100) and Shannon-Wiener index) at the Oden station group were significantly higher than at the C15-site. The reasons for this are unknown so far, since no environmental parameters measured directly at benthic stations are available. The peculiarly higher values of macrofaunal diversity (Shannon-Wiener index) within the cold seeps are known only for a few seep areas, e.g. for the Vestnesa Ridge (Åström et al., 2018), for the South-Western Barents Sea (Sen et al., 2019b) and for the Bahía Blanca estuary in Argentina (Bravo et al., 2018).

383 The station groups revealed by UNKTREE and n-MDS analysis largely corresponded to the 384 geographical position of the C15, Oden and control sites. Twelve common species widely 
385 distributed across the Siberian shelf (Table 2, Sirenko, 2001) were largely responsible for 386 increased integral community parameters in our study. Among such species (based on grab 387 samples) were the polychaetes Spiochaetopterus typicus, Cossura longocirrata and Tharyx sp., 388 the bivalve Macoma calcarea, the amphipod Pleusymtes pulchella and the ophiuroid Ophiocten 389 sericeum. In addition, based on trawl data, the sponge Craniella polyura was present in high 390 densities at the C15 site, together with other filter-feeders including cnidarians and bryozoans

391

392

393

394

395

396

397

398

399

400

401

402

403

404

405

406

407

408

409 (Table 6). Apparently the same species aggregations were visible on the video reported by Baranov et al. (2020). All these above-mentioned species have been previously reported from a wide range of areas of the Laptev Sea and adjacent regions (Sirenko et al., 2004).

The increased density of common taxa at deep-sea hydrothermal vents and cold seeps is a well-known phenomenon usually explained by increased availability of organic matter in these habitats (Hessler \& Kaharl, 1995; Levin, 2005). In the Arctic, the increased biomass and abundance of common allochthonous species were reported for the Håkon Mosby mud volcano (Rybakova et al., 2013), Svalbard (Åström et al., 2016) and Vestnesa Ridge cold seeps (Åström et al., 2018). Also, a significant increase of abundance of filter feeders (especially sponges) was shown for the Aurora Seamount on the Gakkel Ridge, the only investigated hydrothermal vent in the Central Arctic Ocean (Boetius, 2015; Bünz et al, 2019). Soft corals and crinoids were reported to be abundant around the vent fields on the Mohn's Ridge (Sweetman et al., 2013).

Fig. 7. Taxa found only at seep stations.

A - Oligobrachia sp. (left - tube with several fragments enlarged; center - complete specimen extracted from tube; right - anterior and posterior fragments of the specimen); B - Frigidalvania sp.; C Ophryotrocha sp. (upper left - several specimens, total view; upper right - anterior fragment; lower enlarged parapodia); D - Axinopsida orbiculata. Photos by A. Vedenin and V. Kokarev.

410

411

412

413

414

415

416

\section{Taxa specific for methane seep sites}

In our study, the most characteristic species from methane seep sites was the siboglinid Oligobrachia sp. (Fig. 7a). This species was present at all seep station and absent at all background/control station. This species is morphologically very close to Oligobrachia haakonmosbiensis originally described from the Håkon Mosby mud volcano from the depth of $\sim 1200 \mathrm{~m}$ (Smirnov, 2000). Colonies of O. haakonmosbiensis with the biomass reaching $350 \mathrm{~g}$ Ww $\mathrm{m}^{-2}$ were reported from this area (Gebruk et al., 2003). Recent phylogenetical analyses 
417 showed that the species from the Laptev Sea belongs to a separate, undescribed species of 418 Oligobrachia (Sen et al., 2018). In the Laptev Sea, Oligobrachia sp. is known from different 419 localities, seep and noon-seep, occurring in a wide depth range 100-2166 m (Buzhinskaja, 2010). 420 Our record at $63 \mathrm{~m}$ is the shallowest for this species, with high population density and biomass: $421>1000$ ind. $\mathrm{m}^{-2}$ and $45 \mathrm{~g} \mathrm{ww} \mathrm{m}^{-2}$ at Stat. 2623-1 and 5953-2 (Oden site). Several specimens from 422 2015-samples (identified as $O$. haakonmosbiensis) were investigated using transmission electron

423 microscopy (Savvichev et al., 2018). Usually the endosymbionts of siboglinids are represented by sulphide-oxidizing bacteria (Rodrigues et al., 2011; Lee e al., 2019), however in the study of Savvichev et al. (2018), the methanotrophic bacteria were found inside the trophosome.

Additionally to the siboglinids, several samples from the seep-sites were also characterized by high abundance of mollusk species. The gastropod Frigidalvania sp. (Rissoidae) occurred in high density at $C 15$ site: up to 2340 ind. $\mathrm{m}^{-2}$ and $25 \mathrm{~g} \mathrm{ww} \mathrm{m}^{-2}$ at St. 5625-3 (Fig. 7b). According to trawl samples, this species occurs at the Oden site, but in very low numbers (only $2.4 \%$ from total abundance, see Table 5). This species is presumably new to science, based on the presence of a single spiral rib and the absence of knobs, that distinguish it from all known Arctic Frigidalvania species (Warén, 1974). Subfossils of similar unidentified Frigidalvania were found by Thomsen et al. (2019) in the sediment cores at the Vestnesa Ridge cold seeps. Large numbers of unknown rissoid gastropods were previously reported from the Håkon Mosby mud volcano, referred to as Alvania sp. in Gebruk et al. (2003). The stable isotope analysis showed that the rissoids from the HMMV actively graze on bacterial mats (Decker \& Olu, 2012). Furthermore, another rissoid gastropod, Pseudosetia griegi, was observed grazing on bacterial mats at the hot vent Loki Castle on the Mohn's Ridge (Sweetman et al., 2013). At the recently investigated Lofoten canyon seep site dense aggregations of unidentified rissoids were observed on photographs from ROV (Sen et al., 2019a). The details available from the published photo in Sen et al. (2019a) (see Fig. 4b) allow us to suggest that the gastropods are likely to belong to genus Frigidalvania, based on the shell shape and rusty-brownish periostracum. Unfortunately, in our study we were not able to identify the behavior or lifestyle of Frigidalvania sp. This species remained unnoticed in the video data due to its small size (Baranov et al., 2020). However, multiple bacterial mats observed from video-transects and caught by box corer provide an opportunity for such species to graze on them (Savvichev et al., 2018; Baranov et al., 2020). Other species common at the seep sites in this study, however missing in the background/control 
448 was the thyasirid bivalve Axinopsida orbiculata (Fig. 7d). Some species of thyasirids are known

449 as symbiotrophic, however, the information on symbiotic bacteria in the gills of $A$. orbiculata is 450 controversial: Zhukova, Kharlamenko \& Gebruk (1991) have demonstrated the presence of 451 bacteria in bivalve specimens from the Kraternaya Bight, the Kuril Islands, whereas according to 452 Dufour (2005) this species lacks bacterial symbionts. It is possible that the high densitiy of $A$. 453 orbiculata is attributed to increased food availability at seep sites. Overall, no bivalves restricted 454 to cold seeps are known so far in the Arctic with the exception of two large thyasirids recently 455 described based on few empty shells (Åström, Oliver \& Carroll, 2017) and Pleistocene subfossils 456 (e.g. Archivesica spp., Sirenko et al., 2004; Hansen et al., 2017) found deep in the sediment at 457 formerly and/or presently active cold seeps and hydrothermal vents. The subfossils suggest that 458 the Arctic cold seeps (and possibly hydrothermal vents) could be inhabited by richer fauna 459 during late Pleistocene that became extinct during or after Quaternary glaciation (Discussed in 460 Kim et al., 2006; Hansen et al., 2017; Thomsen et al., 2019).

$461 \quad$ Notable is the high density $\left(>3600\right.$ ind. $\left.\mathrm{m}^{-2}\right)$ of the dorvilleid polychaete Ophryotrocha sp. 462 in one grab sample at C15-seep b station group (Supplementary 1 (Fig. 7c). At least 15 species of

463 464 465

466

467

468

469

470

471

472

473

474

475

476

477

478 Ophtyotrocha have been described from reducing habitats (Taboada et al., 2013; Salvo et al., 2014; Ravara et al., 2015), including two species considered as obligate for cold seeps in the Kagoshima Bay, Japan (Miura, 1997). On the other hand, many species of this genus not restricted to reducing habitats are common in the Arctic seas (Sirenko, 2001).

Another taxon common in reducing habitats is tanaid crustaceans (Tanaidacea) (Larsen, 2006; Błażewicz-Paszkowycz \& Bamber, 2011; Zeppilli et al., 2011). In our material three species were present (Supplementary 1), all widely distributed in the Arctic (Sirenko, 2001). The density of tanaids in our samples was low, although this taxon was reported in high densities from the Håkon Mosby mud volcano (Gebruk et al., 2003) and the Vestnesa Ridge (Åström et al., 2018) with several species (described as new) restricted to the methane seep habitats (Błażewicz-Paszkowycz \& Bamber, 2011). It seems likely that many species of tanaids remain unidentified and diversity in this taxon remains underestimated owing to difficulties of identification of these small crustaceans (summarized by Błażewicz-Paszkowycz \& Bamber, 2011). The low number of tanaids in our samples could be a result of a too large sieve mesh size used onboard (see Materials \& Methods). Tanaids commonly are $<0.5 \mathrm{~mm}$ in size and require a corresponding mesh size to be found (Pavithran et al., 2009). 
Overall, considering grab and trawl data combined, all the seep-specific taxa were the same 480 at both seep sites. The only exception is the polychaete Ophryotrocha sp., which could be missed 481 from the Oden trawl sample due to the large sieve mesh size (Supplementary 1).

482

\section{Presence of specific benthic communities at C15 and Oden}

484 Up to now no distinct macrofaunal changes in response to methane seeps were reported from the Arctic Ocean at depths $<80 \mathrm{~m}$. In general, at depths $<200 \mathrm{~m}$ both hydrothermal vents and coldseeps are usually colonized by a subset of the local fauna (Tarasov et al., 2005; Dando, 2010). Some species notable at shallow-water methane seeps belong to opportunistic taxa common in various reducing habitats which include siboglinid polychaetes and thyasirid bivalves reported from Skagerrak, Kattegat, coastal areas of Florida, Japan, New Zealand, New Guinea etc. (Southward \& Culter, 1986; Schmaljohann \& Flügel, 1987; Schmaljohann et al., 1990; Malakhov, Obzhirov \& Tarasov, 1992; Gebruk, 2002). The stable isotope data of nitrogen and carbon sources from various cold seeps all over the ocean suggest that food sources of macrofauna at shallow-water methane seeps are largely photosynthesis-based (Southward et al., 1996; Levin et al., 2000; Dando, 2001; Levin, 2005; Dando, 2010). It was suggested that the faunistic depth boundary between the deep-sea and shallow-water vents and seeps at approximately $200 \mathrm{~m}$ is controlled by the amount of organic matter input from the photosynthetic production (decreasing below the photic zone) and the greater number of predators at shallow depths (summarized by Dando, 2010). Seep-obligate species were not reported from depths $<200$ m (Tarasov et al., 2005; Dando, 2010).

At the same time, methane seep habitats even at shallow depths increase a number of 501 microniches owing to increased organic matter availability, variety of substrates (including different types of sediment and carbonate crusts) and repeated disturbance (Sahling et al., 2003; Dando, 2010; Pohlman et al., 2017; Åström et al., 2019). Therefore, shallow cold-seeps may support greater species diversity (in terms of both richness and diversity indices) compared to the background. In our study at two methane seep sites, C15 and Oden, integral community characteristics were significantly different from those in non-seep areas partially due to presence several station groups and were more scattered at the n-MDS plot (Fig. 2A, B) which could 
509 indicate a larger diversity of microniches within this site. Large amount of filter-feeders

510 (Hydrozoa and Bryozoa) found in C15-trawl indicates the presence of hard substrata (including 511 carbonate crusts). The larger amount of microniches is partly supported by the video-data, where 512 the landscape within the active seepages was more complex than in non-seep areas (Flint et al., 513 2018; Baranov et al., 2020).

514 Overall, the impact of carbon of different origin and the methane-induced habitat 515 heterogeneity are difficult to separate unless the detailed measurements of environmental 516 parameters and isotope ratios from different organisms are obtained. The isotope data are 517 currently available only for the siboglinid Oligobrachia sp., indicating the leading role of 518 microbial methane oxidation in the nutrition of these symbiotrophic worms (Savvichev et al., 519 2018).

520 Recent studies conducted at several seep sites south of Svalbard ( 300 m depth) showed a 521 certain input of chemosynthesis-based carbon into the largely photosynthesis-based local benthic 522 food web (Åström et al., 2019). As an example, the diet of several heterotrophic species, also 523 present in our samples (e.g. polychaetes Nephtys sp. and Scoletoma fragilis) consisted of 524 chemosynthesis-derived organic at the level of 30-40\% (Åström et al., 2019). Isotope-based 525 nutritional investigations of shallow-water cold seeps in the North Sea, Northern California and 526 Kattegat showed little or no chemosynthetic contribution to macrofaunal diet (Dando et al., 527 1991; Jensen et al., 1992; Levin et al., 2000). Based on the increase of density of many species 528 at the seep sites compared to the background (Table 2), it can be assumed that the 529 chemosynthesis-based organic may contribute to the diet of heterotrophic species, such as 530 Nephtyidae polychaetes and other taxa.

531 Unfortunately, no environmental data except for the echo-sounding showing gas 532 emissions and CTD-measurements obtained from the area of the seeps from only two stations 533 (both away from the benthic sampling sites) are available (Flint et al., 2018; Baranov et al., 534 2020). Nevertheless, we suggest that response of macrofauna to methane seepage at shallow 535 depths $60-70 \mathrm{~m}$ can be related to very low primary productivity on the outer shelf of the Laptev 536 Sea, dropping from $\sim 720 \mathrm{mg} \mathrm{C} \mathrm{m}^{-2}$ per day at Lena river delta to $<100 \mathrm{mg} \mathrm{C} \mathrm{m}^{-2}$ per day at 600 $537 \mathrm{~km}$ (Sorokin \& Sorokin, 1996) during September. Outside short Arctic summer, these values 538 decrease to almost zero. In these extremely oligotrophic conditions, methane as a source of 539 energy for the methane-oxidizing bacteria stimulates the development of local patchy benthic 
540 communities even at a shallow depth. As a comparison, the specific communities with 541 siboglinids around Svalbard located at similar latitude are developed only at depths $>200 \mathrm{~m}$, 542 whereas at $80 \mathrm{~m}$ no response of macrofauna is observed ( $\AA$ ström et al., 2016). Unlike the Laptev

543 Sea shelf, the primary production south and west off Svalbard reaches much higher values up to $5441800 \mathrm{mg} \mathrm{C} \mathrm{m}^{-2}$ per day during May blooms (Wassman et al., 2006). Furthermore, the Barents 545 Sea remains uncovered with ice during most of the year, while the Laptev Sea shelf is ice-free 546 during one to two months annually. Other examples of shallow-water cold seeps with little or no 547 macrofaunal response are also located in non-oligotrophic areas, such as the North Sea pockmark 548 at $150 \mathrm{~m}$ depth with pelagic production up to $1300 \mathrm{mg} \mathrm{C} \mathrm{m}^{-2}$ per day (Moll, 1998; Dando et al., 549 1991) and the Baltic Sea pockmarks with $>2000 \mathrm{mg} \mathrm{C} \mathrm{m}^{-2}$ per day in April (Lignell, 1990; 550 Pimenov et al., 2008).

551 The only investigated shallow-water reducing habitat comparable in the primary 552 production level to the Laptev Sea is the hydrothermal vent of the volcanic Deception Island, 553 Antarctica. Environmental conditions in the inner bay (Port Foster) of the Deception Island are 554 oligotrophic, most of the surface is ice-covered during austral winter (Bright et al., 2003; 555 Angulo-Preckler et al., 2017). However, several fumaroles and hot springs in Port Foster, located 556 from intertidal to $\sim 15 \mathrm{~m}$ depth enrich the surrounding waters with sulfides and methane and keep 557 the sea surface above them ice-free (Tilbrook and Karl, 1993). Certain increase of local 558 macrofauna around the hot springs was described recently (Angulo-Preckler et al., 2017). In 559 addition, one taxon, apparently restricted to reducing habitat, was found in the sediment around 560 the hydrothermal vents. The new taxon was a monocelid flat worm, covered with 561 chemoautotrophic bacteria (Bright et al., 2003). However, no seep-specific macrobenthic 562 communities were observed in Port Foster (Angulo-Preckler et al., 2017), presumably owing to 563 the very shallow depth: the maximum chemoautotrophic activity and the peak abundance of 564 monocelid worms were recorded at 1-2 m depth (Bright et al., 2003).

565 To confirm the relationship between the depth where the seep-specific communities can 566 develop and the primary production, more shallow-water cold seeps at the extremely 567 oligotrophic conditions (e.g. polar areas) should be investigated. 


\section{Conclusions}

569 Our study is the first description of shallow-water methane seep communities in the Siberian 570 Arctic. On the northern Laptev Sea shelf, significant differences were found among two methane 571 seep sites (C15 and Oden, located at depths of 63-73 m) and the background areas. The 572 differences included integral community parameters and presence at seep sites of species typical 573 for reducing habitats, such as siboglinids Oligobrachia sp. and thyasirid bivalves. Several 574 species at methane seeps are presumably new to science, including the gastropod Frigidalvania 575 sp. and the polychaete Ophryotrocha sp., found in large densities at C15 site. We suggest that the 576 distinct influence of methane discharges on macrofauna is more prominent in oligotrophic 577 settings such as the outer shelf of the Laptev Sea.

578

\section{Acknowledgements}

580 The authors would like to thank the Captain, crew members and shipboard parties of the RV 581 Akademik Mstislav Keldysh for multiple help with the work onboard during the 63, 69 and 72 582 expeditions. Our special thanks to Dr. Michael Flint for organizing the expeditions and for 583 informative discussions. We also thank Dr. Alexey Udalov and Dr. Elena Krylova for help in 584 identifying mollusks and crustaceans. This work was partly funded by RFBR Grants 18-04585 00206, 18-05-60053, 18-05-60228 and the State assignment of IORAS (theme No 0149-2019586 0009). 
587

588

589

590

591

592

593

594

595

596

597

598

599

600

601

602

603

604

605

606

607

608

609

610

611

612

613

614

615

616

617

618

619

620

621

622

623

624

625

626

627

628

629

630

\section{References}

1. Angulo-Preckler, C., Leiva, C., Avila, C., \& Taboada, S. (2017). Macroinvertebrate communities from the shallow soft-bottoms of Deception Island (Southern Ocean): a paradise for opportunists. Marine environmental research, 127, 62-74.

2. Åström, E. K., Carroll, M. L., Ambrose Jr, W. G., \& Carroll, J. (2016). Arctic cold seeps in marine methane hydrate environments: impacts on shelf macrobenthic community structure offshore Svalbard. Marine Ecology Progress Series, 552, 1-18.

3. Åström, E. K., Oliver, P. G., \& Carroll, M. L. (2017). A new genus and two new species of Thyasiridae associated with methane seeps off Svalbard, Arctic Ocean. Marine Biology Research, 13(4), 402-416.

4. Åström, E. K., Carroll, M. L., Ambrose Jr, W. G., Sen, A., Silyakova, A., \& Carroll, J. (2018). Methane cold seeps as biological oases in the high-Arctic deep sea. Limnology and Oceanography, 63(S1), S209-S231.

5. Åström, E. K., Carroll, M. L., Sen, A., Niemann, H., Ambrose Jr, W. G., Lehmann, M. F., \& Carroll, J. (2019). Chemosynthesis influences food web and community structure in highArctic benthos. Marine Ecology Progress Series, 629, 19-42.

6. Azovsky, A.I. (2018) Analysis of long-term biological data series: methodological problems and possible solutions. J Gene Biol (Moscow) 79:329-341 [in Russian]

7. Baker, E. T., \& German, C. R. (2004). On the global distribution of hydrothermal vent fields. Mid-Ocean Ridges: Hydrothermal Interactions Between the Lithosphere and Oceans, Geophys. Monogr. Ser, 148, 245-266.

8. Baranov B., Galkin S., Vedenin A., Dozorova K., Gebruk A., Flint M. 2020. Methane seeps on the outer shelf of the Laptev Sea: characteristic features, benthic fauna and structural control. Geophysical Research Letters. [in press]

9. Barnes, D. K., Linse, K., Enderlein, P., Smale, D., Fraser, K. P., \& Brown, M. (2008). Marine richness and gradients at Deception Island, Antarctica. Antarctic Science, 20(3), 271-280.

10. Bergquist, D. C., Ward, T., Cordes, E. E., McNelis, T., Howlett, S., Kosoff, R., ... \& Fisher, C. R. (2003). Community structure of vestimentiferan-generated habitat islands from Gulf of Mexico cold seeps. Journal of Experimental Marine Biology and Ecology, 289(2), 197-222.

11. Błażewicz-Paszkowycz, M., \& Bamber, R. N. (2011). Tanaidomorph Tanaidacea (Crustacea: Peracarida) from mud-volcano and seep sites on the Norwegian Margin. Zootaxa, 3061, 1-35.

12. Boetius, A. (2015). The expedition PS86 of the Research Vessel POLARSTERN to the Arctic Ocean in 2014. Berichte zur Polar-und Meeresforschung $=$ Reports on polar and marine research, 685, 1-132.

13. Bravo, M. E., Aliotta, S., Fiori, S., \& Ginsberg, S. (2018). Distribution, vertical position and ecological implications of shallow gas in Bahía Blanca estuary (Argentina). Estuarine, Coastal and Shelf Science, 202, 222-231.

14. Bright, M., Arndt, C., Keckeis, H., \& Felbeck, H. (2003). A temperature-tolerant interstitial worm with associated epibiotic bacteria from the shallow water fumaroles of Deception Island, Antarctica. Deep Sea Research Part II: Topical Studies in Oceanography, 50(10-11), 1859-1871.

15. Brotskaya, V., Zenkevich, L., 1939. Quantitative account of the Barents Sea benthic fauna. Trudy VNIRO, 4, 55-120. [in Russian] 
631

632

633

634

635

636

637

638

639

640

641

642

643

644

645

646

647

648

649

650

651

652

653

654

655

656

657

658

659

660

661

662

663

664

665

666

667

668

669

670

671

672

673

674

675

16. Bünz, S., Ramirez-Llodra, E., German, C., Ferre, B., Sert, F., Kalenickenko, D., ... \& Purser, A. (2020). RV Kronprins Håkon (cruise no. 2019708) Longyearbyen-Longyearbyen 19.09.16.10. 2019.

17. Buzhinskaja, G. N. (2010). Illustrated keys to free-living invertebrates of Eurasian Arctic seas and adjacent deep waters. Nemertea, Cephalorincha, Oligochaeta, Hirudinea, Pogonophora, Echiura, Sipuncula, Phoronida and Brachiopoda, 2. $186 \mathrm{p}$.

18. Clarke, K.R., Warwick, R.M., 2001. Changes in Marine Communities: An Approach to Statistical Analysis and Interpretation (2nd ed.). PRIMER-E, Plymouth

19. Clarke, K. R., Gorley, R. N. (2015). Getting started with PRIMER v7. PRIMER-E: Plymouth, Plymouth Marine Laboratory.

20. Cordes, E. E., Cunha, M. R., Galeron, J., Mora, C., Olu-Le Roy, K., Sibuet, M., ... \& Levin, L. A. (2010). The influence of geological, geochemical, and biogenic habitat heterogeneity on seep biodiversity. Marine Ecology, 31(1), 51-65.

21. Dando, P. R., Austen, M. C., Burke Jr, R. A., Kendall, M. A., Kennicutt, M. C., Judd, A. G., ... \& Southward, A. J. (1991). Ecology of a North Sea pockmark with an active methane seep. Marine Ecology Progress Series, 49-63.

22. Dando, P. R., Fenchel, T., Jensen, P., O'Hara, S. C. M., Niven, S. J., \& Schuster, U. (1993). Ecology of gassy, organic-rich sediment in a shallow subtidal area on the Kattegat coast of Denmark. Marine Ecology Progress Series, 265-271.

23. Dando, P. R. (2001). A review of pockmarks in the UK part of the North Sea, with particular respect to their biology. Strategic Environmental Assessment-SEA2 Technical Report TR, 1, 21.

24. Dando, P.R., 2010. Biological communities at marine shallow-water vent and seep sites. In: Kiel S. (Ed.) The Vent and Seep Biota, Springer, Dordrecht, pp. 333-378.

25. Van Dover, C. (2000). The ecology of deep-sea hydrothermal vents. Princeton University Press.

26. Decker C., \& Olu K. (2012). Habitat heterogeneity influences cold-seep macrofaunal communities within and among seeps along the Norwegian margin - Part 2: contribution of chemosynthesis and nutritional patterns. Marine Ecology, 33(2), 231-245.

27. Dufour, S. C. (2005). Gill anatomy and the evolution of symbiosis in the bivalve family Thyasiridae. The Biological Bulletin, 208(3), 200-212.

28. Eleftheriou A., McIntyre A. (2005). Methods for the study of Marine benthos. 3rd edn. Blackwell Science, Oxford, UK. 418 p.

29. Flint M., Arashkevich E., Artemyev V., Baranov B., Bezzubova E., Belevich T., ... \& Shchuka S.A. Ecosystems of seas of Siberian Arctic. Materials of expeditionary research of 2015 and 2017. P.P. Shirshov Institute of oceanology, RAS. Moscow: 2018. 232 p. [in Russian]

30. Galkin, S. V., \& Vedenin, A. A. (2015). Macrobenthos of Yenisei Bay and the adjacent Kara Sea shelf. Oceanology, 55(4), 606-613.

31. Gebruk A.V. Biology of hydrothermal vents. Moscow, KMK-Press, 2002. 543 p. [in Russian] 32. Gebruk, A. V., Krylova, E. M., Lein, A. Y., Vinogradov, G. M., Anderson, E., Pimenov, N. V., ... \& Crane, K. (2003). Methane seep community of the Håkon Mosby mud volcano (the Norwegian Sea): composition and trophic aspects. Sarsia, 88(6), 394-403.

33. Hammer, Ø. 2013. PAST. Paleontological Statistics. Version 3.10. Reference manual. Natural History Museum. University of Oslo. 
676

677

678

679

680

681

682

683

684

685

686

687

688

689

690

691

692

693

694

695

696

697

698

699

700

701

702

703

704

705

706

707

708

709

710

711

712

713

714

715

716

717

718

719

720

34. Hansen, J., Hoff, U., Sztybor, K., \& Rasmussen, T. L. (2017). Taxonomy and palaeoecology of two Late Pleistocene species of vesicomyid bivalves from cold methane seeps at Svalbard $\left(79^{\circ} \mathrm{N}\right)$. Journal of Molluscan Studies, 83(3), 270-279.

35. Hessler, R.R., Kaharl, V.A., 1995. The deep-sea hydrothermal vent community: an overview. Seafloor hydrothermal systems. In: Humphris, S.E., Zierenberg, R.A., Mullineaux, L.S.., Thomson, R.E. (Eds.), Geophysical Monograph, vol. 91. American Geo-physical Union, pp. 72-84.

36. Jensen, P., Aagaard, I., Burke Jr, R. A., Dando, P. R., Jorgensen, N. O., Kuijpers, A., ... \& Schmaljohann, R. (1992). 'Bubbling reefs' in the Kattegat: submarine landscapes of carbonatecemented rocks support a diverse ecosystem at methane seeps. Marine Ecology Progress Series, 83, 102-112.

37. Kim B., Rachor, E., Sirenko, B., Aplonov, V., Starobogatov, Y.\& Stein, R. 2006. Termal discharge points on the Gakkel Ridge (Arctic Basin). Russian Academy of Sciences, Zoological Institute. Explorations of the Fauna of the Seas, 56, (64): 5-14.

38. Larsen, K. (2006). Tanaidacea (Crustacea; Peracarida) from chemically reduced habitats-the hydrothermal vent system of the Juan de Fuca Ridge, Escabana Trough and Gorda Ridge, northeast Pacific. Zootaxa, 1164, 1-33.

39. Lee, D. H., Kim, J. H., Lee, Y. M., Jin, Y. K., Paull, C., Kim, D., \& Shin, K. H. (2019). Chemosynthetic bacterial signatures in Frenulata tubeworm Oligobrachia sp. in an active mud volcano of the Canadian Beaufort Sea. Marine Ecology Progress Series, 628, 95-104.

40. Levin, L. A., James, D. W., Martin, C. M., Rathburn, A. E., Harris, L. H., \& Michener, R. H. (2000). Do methane seeps support distinct macrofaunal assemblages? Observations on community structure and nutrition from the northern California slope and shelf. Marine Ecology Progress Series, 208, 21-39.

41. Levin, L. A. (2005). Ecology of cold seep sediments: interactions of fauna with flow, chemistry and microbes. In Oceanography and Marine Biology (pp. 11-56). CRC Press.

42. Lignell, R. (1990). Excretion of organic carbon by phytoplankton: its relation to algal biomass, primary productivity and bacterial secondary productivity in the Baltic Sea. Marine ecology progress series. Oldendorf, 68(1), 85-99.

43. Lobkovsky, L. I., Nikiforov, S. L., Ananiev, R. A., Khortov, A. V., Semiletov, I. P., Jakobsson, M., \& Dmitrievskiy, N. N. (2015). Recent geological-geomorphological processes on the east Arctic shelf: Results of the expedition of the icebreaker Oden in 2014. Oceanology, 55(6), 926-929.

44. Malakhov, V. V., Obzhirov, A. I., \& Tarasov, V. G. (1992). Pogonophoran genus Siboglinum in relation to zones of high concentrations of methane. Doklady Akademii Nauk, 135, 195197. [in Russian]

45. McCune, B., Grace, J.B., Urban, D.L., 2002. Analysis of Ecological Communities. Vol. Mjm Software Design., Gleneden Beach, Oregon, p. 28.

46. Menot, L., Galéron, J., Olu, K., Caprais, J. C., Crassous, P., Khripounoff, A., \& Sibuet, M. (2010). Spatial heterogeneity of macrofaunal communities in and near a giant pockmark area in the deep Gulf of Guinea. Marine Ecology, 31(1), 78-93.

47. Miura, T. (1997). Two new species of the genus Ophryotrocha (Polychaeta, Iphitimiidae) from Kagoshima Bay. Bulletin of Marine Science, 60(2), 300-305.

48. Moll, A. (1998). Regional distribution of primary production in the North Sea simulated by a three-dimensional model. Journal of Marine Systems, 16(1-2), 151-170.

Peer) reviewing PDF | (2019:08:40542:3:0:NEW 19 Mar 2020) 
721

722

723

724

725

726

727

728

729

730

731

732

733

734

735

736

737

738

739

740

741

742

743

744

745

746

747

748

749

750

751

752

753

754

755

756

757

758

759

760

761

762

763

764

765

49. Paull, C. K., Dallimore, S. R., Caress, D. W., Gwiazda, R., Melling, H., Riedel, M., ... \& Sherman, A. (2015). Active mud volcanoes on the continental slope of the C anadian B eaufort S ea. Geochemistry, Geophysics, Geosystems, 16(9), 3160-3181.

50. Pavithran, S., Ingole, B., Nanajkar, M., \& Goltekar, R. (2009). Importance of sieve size in deep-sea macrobenthic studies. Marine Biology Research, 5(4), 391-398.

51. Pimenov, N. V., Ul'yanova, M. O., Kanapatskii, T. A., Sivkov, V. V., \& Ivanov, M. V. (2008). Microbiological and biogeochemical processes in a pockmark of the Gdansk Depression, Baltic Sea. Microbiology, 77(5), 579-586.

52. Pohlman, J. W., Greinert, J., Ruppel, C., Silyakova, A., Vielstädte, L., Casso, M., ... \& Bünz, S. (2017). Enhanced CO2 uptake at a shallow Arctic Ocean seep field overwhelms the positive warming potential of emitted methane. Proceedings of the National Academy of Sciences, 114(21), 5355-5360.

53. Powell, E. N., Bright, T. J., \& Brooks, J. M. (1986). The effect of sulfide and an increased food supply on the meiofauna and macrofauna at the East Flower Garden brine seep. Helgoländer Meeresuntersuchungen, 40(1-2), 57-82.

54. R Development Core Team, 2020. The R Project for Statistical Computing. R Foundation for Statistical Computing, Vienna, Austria, http://www.R-project.org (Accessed on 13/03/2020).

55. Ravara, A., Marçal, A. R., Wiklund, H., \& Hilário, A. (2015). First account on the diversity of Ophryotrocha (Annelida, Dorvilleidae) from a mammal-fall in the deep-Atlantic Ocean with the description of three new species. Systematics and biodiversity, 13(6), 555-570.

56. Rodrigues, C. F., Hilário, A., Cunha, M. R., Weightman, A. J., \& Webster, G. (2011). Microbial diversity in Frenulata (Siboglinidae, Polychaeta) species from mud volcanoes in the Gulf of Cadiz (NE Atlantic). Antonie Van Leeuwenhoek, 100(1), 83-98.

57. Rybakova, E., Galkin, S., Bergmann, M., Soltwedel, T., \& Gebruk, A. (2013). Density and distribution of megafauna at the Håkon Mosby mud volcano (the Barents Sea) based on image analysis. Biogeosciences, 10, 3359-3374.

58. Sahling, H., Galkin, S. V., Salyuk, A., Greinert, J., Foerstel, H., Piepenburg, D., \& Suess, E. (2003). Depth-related structure and ecological significance of cold-seep communities - a case study from the Sea of Okhotsk. Deep Sea Research Part I: Oceanographic Research Papers, 50(12), 1391-1409.

59. Salvo, F., Wiklund, H., Dufour, S. C., Hamoutene, D., Pohle, G., \& Worsaae, K. (2014). A new annelid species from whalebones in Greenland and aquaculture sites in Newfoundland: Ophryotrocha cyclops, sp. nov.(Eunicida: Dorvilleidae). Zootaxa, 3887(5), 555-568.

60. Savvichev A.S., Rusanov I.I., Yusupov S.K., Pimenov N.V., Lein A.Y., \& Ivanov M.V. 2004. The biogeochemical cycle of methane in the coastal zone and littoral of the Kandalaksha Bay of the White Sea. Microbiology, 73(4), 457-468.

61. Savvichev, A. S., Kadnikov, V. V., Kravchishina, M. D., Galkin, S. V., Novigatskii, A. N., Sigalevich, P. A., ... \& Flint, M. V. (2018). Methane as an organic matter source and the trophic basis of a Laptev Sea cold seep microbial community. Geomicrobiology journal, 35(5), 411-423.

62. Schmaljohann, R., \& Flügel, H. J. (1987). Methane-oxidizing bacteria in Pogonophora. Sarsia, 72(1), 91-98.

63. Schmaljohann, R., Faber, E., Whiticar, M. J., \& Dando, P. R. (1990). Co-existence of methane-and sulphur-based endosymbioses between bacteria and invertebrates at a site in the Skagerrak. Marine Ecology Progress Series, 61, 119-124.

Peer) reviewing PDF | (2019:08:40542:3:0:NEW 19 Mar 2020) 
766

767

768

769

770

771

772

773

774

775

776

777

778

779

780

781

782

783

784

785

786

787

788

789

790

791

792

793

794

795

796

797

798

799

800

801

802

803

804

805

806

807

808

809

64. Sen A., Duperron S., Hourdez S., Piquet B., Le'ger N., Gebruk A., Le Port A.S., Svenning M.M., \& Andersen A.C. (2018) Cryptic frenulates are the dominant chemosymbiotrophic fauna at Arctic and high latitude Atlantic cold seeps. PLoS ONE, 13(12): e0209273.

65. Sen A., Himmler T., Hong W.L., Chitkara C., Lee R.W., Ferré B., ... \& Knies J. (2019a). Atypical biological features of a new cold seep site on the Lofoten-Vesterålen continental margin (northern Norway). Scientific reports, 9(1), 1762.

66. Sen, A., Chitkara, C., Hong, W. L., Lepland, A., Cochrane, S., di Primio, R., \& Brunstad, H. (2019b). Image based quantitative comparisons indicate heightened megabenthos diversity and abundance at a site of weak hydrocarbon seepage in the southwestern Barents Sea. PeerJ, 7, e7398.

67. Shakhova, N., Semiletov, I., Sergienko, V., Lobkovsky, L., Yusupov, V., Salyuk, A., ... \& Nicolsky, D. (2015). The East Siberian Arctic Shelf: towards further assessment of permafrost-related methane fluxes and role of sea ice. Philosophical Transactions of the Royal Society A: Mathematical, Physical and Engineering Sciences, 373(2052), 20140451.

68. Sirenko, B. I. (2001). List of species of free-living invertebrates of Eurasian Arctic seas and adjacent deep waters. Explorations of the fauna of the seas, 51(59), 5-131.

69. Sirenko B., Denisenko S., Deubel H., \& Rachor E. (2004). Deep water communities of the Laptev Sea and adjacent parts of the Arctic Ocean. Fauna and the ecosystems of the Laptev Sea and adjacent deep waters of the Arctic Ocean. Explorations of the fauna of sea, 54(62), 28-73.

70. Smirnov, R. V. (2000). Two new species of Pogonophora from the arctic mud volcano off northwestern Norway. Sarsia, 85(2), 141-150.

71. Sommer, S., Linke, P., Pfannkuche, O., Schleicher, T., Deimling, J. S. V., Reitz, A., ... \& Hensen, C. (2009). Seabed methane emissions and the habitat of frenulate tubeworms on the Captain Arutyunov mud volcano (Gulf of Cadiz). Marine Ecology Progress Series, 382, 6986.

72. Sorokin, Y. I., \& Sorokin, P. Y. (1996). Plankton and primary production in the Lena River estuary and in the south-eastern Laptev Sea. Estuarine, Coastal and Shelf Science, 43(4), 399418.

73. Southward, E. C., \& Culter, J. K. (1986). Discovery of Pogonophora in warm shallow waters of the Florida Shelf. Marine Ecology Progress Series, 28, 287-89.

74. Southward, A. J., Kennicutt, M. C., Herrera-Alcalà, J., Abbiati, M., Airoldi, L., Cinelli, F., ... \& Southward, E. C. (1996). On the biology of submarine caves with sulphur springs: appraisal of $13 \mathrm{C} / 12 \mathrm{C}$ ratios as a guide to trophic relations. Journal of the Marine Biological Association of the United Kingdom, 76(2), 265-285.

75. Sweetman, A. K., Levin, L., Rapp, H. T., \& Schander, C., 2013. Faunal trophic structure at hydrothermal vents on the southern Mohn's Ridge, Arctic Ocean. Marine Ecology Progress Series, 473, 115-131.

76. Taboada, S., Wiklund, H., Glover, A. G., Dahlgren, T. G., Cristobo, J., \& Avila, C. (2013). Two new Antarctic Ophryotrocha (Annelida: Dorvilleidae) described from shallow-water whale bones. Polar Biology, 36(7), 1031-1045.

77. Tarasov, V. G., Gebruk, A. V., Mironov, A. N., \& Moskalev, L. I. (2005). Deep-sea and shallow-water hydrothermal vent communities: two different phenomena? Chemical Geology, 224(1-3), 5-39.

Peer) reviewing PDF | (2019:08:40542:3:0:NEW 19 Mar 2020) 
810

811

812

813

814

815

816

817

818

819

820

821

822

823

824

825

826

827

828

829

830

831

832

833

834

835

836

837

838

839

78. Thomsen, E., Rasmussen, T. L., Sztybor, K., Hanken, N. M., Tendal, O. S., \& Uchman, A. (2019). Cold-seep fossil macrofaunal assemblages from Vestnesa Ridge, eastern Fram Strait, during the past 45000 years. Polar Research, 38, 3310. Doi: 10.33265/polar.v38.3310

79. Thornton, B.F., Geibel, M.C., Crill, P.M., Humborg, C., Mörth, C.-M. (2016). Methane fluxes from the sea to the atmosphere across the Siberian shelf seas. Geophys Res Lett 43, 58695877 ,

80. Tilbrook, B. D., \& Karl, D. M. (1993). RACER: Methane enrichments in Port Foster, Deception Island. Antarctic Journal of the United States; (United States), 28(5).

81. Vedenin, A. A., Galkin, S. V., \& Kozlovskiy, V. V. (2015). Macrobenthos of the Ob Bay and adjacent Kara Sea shelf. Polar Biology, 38(6), 829-844.

82. Vedenin, A., Mokievsky, V., Soltwedel, T., \& Budaeva, N. (2019). The temporal variability of the macrofauna at the deep-sea observatory HAUSGARTEN (Fram Strait, Arctic Ocean). Polar Biology, p. 1-14. doi.org/10.1007/s00300-018-02442-8.

83. Warén, A. (1974). Revision of the Arctic-Atlantic Rissoidae (Gastropoda, Prosobranchia). Zoologica Scripta, 3(3), 121-135.

84. Wassmann, P., Reigstad, M., Haug, T., Rudels, B., Carroll, M. L., Hop, H., ... \& Slagstad, D. (2006). Food webs and carbon flux in the Barents Sea. Progress in Oceanography, 71(2-4), 232-287.

85. Yusupov, V. I., Salyuk, A. N., Karnaukh, V. N., Semiletov, I. P., \& Shakhova, N. E. (2010). Detection of methane ebullition in shelf waters of the Laptev Sea in the Eastern Arctic Region. In: Doklady Earth Sciences (Vol. 430, No. 2, pp. 261-264). MAIK Nauka/Interperiodica.

86. Zeppilli, D., Mea, M., Corinaldesi, C., \& Danovaro, R. (2011). Mud volcanoes in the Mediterranean Sea are hot spots of exclusive meiobenthic species. Progress in Oceanography, 91(3), 260-272.

87. Zhukova, N.V., V.I. Kharlamenko \& Gebruk A.V., 1991. Fatty acids of Axinopsida orbiculata - potential for detection of symbiosis with chemoautotrophic bacteria. In, Shallow Water Vents and Ecosystem oJ Kraternaya Bight (Volcano Ushishir. Kurile Islands), Vol. 1, Functional Characteristics, Part 11, Vladivostok, in press. [In Russian].

Peer] reviewing PDF | (2019:08:40542:3:0:NEW 19 Mar 2020) 


\section{Table 1 (on next page)}

Data on stations used in the present study

For trawl stations coordinates and depth of start and end are given 
1 Table 1. Data on stations used in the present study. For trawl stations coordinates and depth of start and 2 end are given.

\begin{tabular}{|c|c|c|c|c|c|c|}
\hline $\begin{array}{c}\text { Expedition, } \\
\text { year }\end{array}$ & Station & Site & Gear & Latitude & Longitude & $\begin{array}{c}\text { Depth } \\
\text { (m) }\end{array}$ \\
\hline \multirow{7}{*}{ 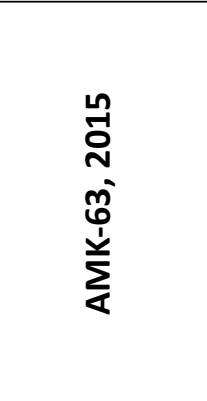 } & seep-1 & C15 & Okean-0.1 & $76^{\circ} 46.376^{\prime} \mathrm{N}$ & $125^{\circ} 49.641^{\prime} \mathrm{E}$ & 72.0 \\
\hline & seep-2 & C15 & Okean-0.1 & $76^{\circ} 46.376^{\prime} \mathrm{N}$ & $125^{\circ} 49.664^{\prime} \mathrm{E}$ & 72.3 \\
\hline & seep-3 & C15 & Okean-0.1 & $76^{\circ} 46.379^{\prime} \mathrm{N}$ & $125^{\circ} 49.618^{\prime} \mathrm{E}$ & 72.4 \\
\hline & background-1 & C15 & Okean-0.1 & $76^{\circ} 46.375^{\prime} \mathrm{N}$ & $125^{\circ} 50.346^{\prime} \mathrm{E}$ & 73.0 \\
\hline & background-2 & C15 & Okean-0.1 & $76^{\circ} 46.366^{\prime} \mathrm{N}$ & $125^{\circ} 50.366^{\prime} \mathrm{E}$ & 73.0 \\
\hline & background-3 & C15 & Okean-0.1 & $76^{\circ} 46.365^{\prime} \mathrm{N}$ & $125^{\circ} 50.339^{\prime} \mathrm{E}$ & 73.0 \\
\hline & C15 trawl & C15 & Sigsbee & $\begin{array}{l}76^{\circ} 46.483^{\prime} \mathrm{N} \\
76^{\circ} 46.447^{\prime} \mathrm{N}\end{array}$ & $\begin{array}{l}125^{\circ} 50.843^{\prime} \mathrm{E} \\
125^{\circ} 48.231^{\prime} \mathrm{E}\end{array}$ & $\begin{array}{l}71.5 \\
72.0\end{array}$ \\
\hline \multirow{10}{*}{ 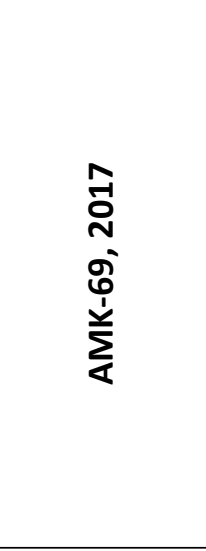 } & $5623-1$ & Oden & Van Veen-0.1 & $76^{\circ} 53.624^{\prime} \mathrm{N}$ & $127^{\circ} 48.110^{\prime} \mathrm{E}$ & 63.0 \\
\hline & $5623-2$ & Oden & Van Veen-0.1 & $76^{\circ} 53.608^{\prime} \mathrm{N}$ & $127^{\circ} 48.114^{\prime} \mathrm{E}$ & 63.1 \\
\hline & $5623-3$ & Oden & Van Veen-0.1 & $76^{\circ} 53.632^{\prime} \mathrm{N}$ & $127^{\circ} 48.219^{\prime} \mathrm{E}$ & 63.0 \\
\hline & Oden trawl & Oden & Sigsbee & $\begin{array}{l}76^{\circ} 53,667^{\prime} N \\
76^{\circ} 53,566^{\prime} N\end{array}$ & $\begin{array}{l}127^{\circ} 48,157^{\prime} \mathrm{E} \\
127^{\circ} 49,075^{\prime} \mathrm{E}\end{array}$ & $\begin{array}{l}63.0 \\
63.0\end{array}$ \\
\hline & $5624-1$ & Control & Van Veen-0.1 & $76^{\circ} 49.998^{\prime} \mathrm{N}$ & $126^{\circ} 39.936^{\prime} \mathrm{E}$ & 69.6 \\
\hline & $5624-2$ & Control & Van Veen-0.1 & $76^{\circ} 50.003^{\prime} \mathrm{N}$ & $126^{\circ} 39.896^{\prime} \mathrm{E}$ & 69.7 \\
\hline & $5624-3$ & Control & Van Veen-0.1 & $76^{\circ} 49.883^{\prime} N$ & $126^{\circ} 40.000^{\prime} \mathrm{E}$ & 69.6 \\
\hline & $5625-1$ & C15 & Van Veen-0.1 & $76^{\circ} 46.438^{\prime} \mathrm{N}$ & $125^{\circ} 49.417^{\prime} \mathrm{E}$ & 70.8 \\
\hline & $5625-2$ & C15 & Van Veen-0.1 & $76^{\circ} 46.435^{\prime} \mathrm{N}$ & $125^{\circ} 49.442^{\prime} \mathrm{E}$ & 70.7 \\
\hline & $5625-3$ & C15 & Van Veen-0.1 & $76^{\circ} 46.413^{\prime} \mathrm{N}$ & $125^{\circ} 49.437^{\prime} \mathrm{E}$ & 70.6 \\
\hline \multirow{6}{*}{ 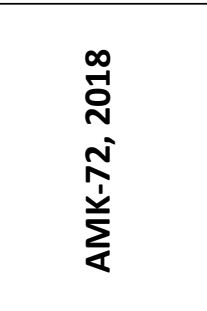 } & $5947-1$ & C15 & Van Veen-0.1 & $76^{\circ} 46.847^{\prime} \mathrm{N}$ & $125^{\circ} 49.085^{\prime} \mathrm{E}$ & 72.3 \\
\hline & $5947-2$ & $C 15$ & Van Veen-0.1 & $76^{\circ} 46.847^{\prime} \mathrm{N}$ & $125^{\circ} 49.085^{\prime} \mathrm{E}$ & 72.0 \\
\hline & $5947-3$ & $C 15$ & Van Veen-0.1 & $76^{\circ} 46.848^{\prime} \mathrm{N}$ & $125^{\circ} 49.097^{\prime} \mathrm{E}$ & 72.0 \\
\hline & $5953-1$ & Oden & Van Veen-0.1 & $76^{\circ} 53.554^{\prime} \mathrm{N}$ & $127^{\circ} 48.405^{\prime} \mathrm{E}$ & 63.0 \\
\hline & $5953-2$ & Oden & Van Veen-0.1 & $76^{\circ} 53.551^{\prime} \mathrm{N}$ & $127^{\circ} 48.409^{\prime} \mathrm{E}$ & 63.0 \\
\hline & $5953-3$ & Oden & Van Veen-0.1 & $76^{\circ} 53.567^{\prime} \mathrm{N}$ & $127^{\circ} 48.400^{\prime} \mathrm{E}$ & 63.0 \\
\hline
\end{tabular}




\section{Table 2 (on next page)}

Results of the Kruskal-Wallis and Dunn's post-hoc tests for taxa with different abundance values in five station groups

Mean abundance in each station group is shown (ind. $\mathrm{m}^{-2}$ ). Taxa are arranged according to $p$-value. Pairs in Dunn's pairwise comparisons column indicate significant comparisons (Dunn's $p<\alpha / 2=0.025$ )

1 - Control group; 2 - C15 background group; 3 - Oden group; 4 - C15-seep a group; 5 - C15-seep-b group 
1 Table 2. Results of the Kruskal-Wallis and Dunn's post-hoc tests for taxa with different abundance values 2 in five station groups. Mean abundance in each station group is shown. Taxa are arranged according to $p$ 3 value. Pairs in Dunn's pairwise comparisons column indicate significant comparisons (Dunn's $p<$ $4 \alpha / 2=0.025)$.

\begin{tabular}{|c|c|c|c|c|c|c|c|c|}
\hline \multirow{2}{*}{ Species } & \multicolumn{5}{|c|}{ Mean abundance in station groups } & \multicolumn{2}{|c|}{ Kruskal-Wallis } & \multirow{2}{*}{$\begin{array}{c}\text { Dunn's pairwise } \\
\text { comparisons }\end{array}$} \\
\hline & 1 & 2 & 3 & 4 & 5 & $H\left(\mathrm{chi}^{2}\right)$ & $p$ & \\
\hline Oligobrachia sp. & 0 & 0 & 63.0 & 14.6 & 53.5 & 16.80 & 0 & $1-3 ; 2-3$ \\
\hline Nephtys ciliata & 0 & 0 & 2.2 & 1.6 & 0 & 15.72 & 0 & $2-3$ \\
\hline Yoldiella lenticula & 0.7 & 12.6 & 1.0 & 8.8 & 2.0 & 15.59 & 0 & $2-3$ \\
\hline Cistenides hyperborea & 0 & 0.4 & 0.2 & 4.4 & 5.5 & 13.49 & 0 & $3-4$ \\
\hline Tharyx sp. & 2.3 & 6.0 & 32.5 & 3.8 & 2.5 & 14.81 & 0.01 & $1-3 ; 3-4$ \\
\hline Spiochaetopterus typicus & 0 & 0 & 3.0 & 0.6 & 0 & 12.95 & 0.01 & $2-3$ \\
\hline Yoldiella solidula & 9.3 & 44.0 & 23.5 & 19.6 & 5.0 & 12.51 & 0.01 & $2-5$ \\
\hline Cossura longocirrata & 0 & 0 & 0.2 & 0.6 & 199.0 & 11.47 & 0.02 & $1-5 ; 2-5 ; 3-5$ \\
\hline Ophiocten sericeum & 0.3 & 3.8 & 6.3 & 4.8 & 26.5 & 10.52 & 0.03 & $1-5$ \\
\hline Portlandia arctica & 0 & 14.6 & 0 & 0.8 & 0.5 & 10.52 & 0.03 & $2-3$ \\
\hline Pleusymtes pulchella & 0 & 0 & 0.5 & 1.2 & 3.5 & 10.37 & 0.03 & no values \\
\hline Frigidalvania sp. & 0 & 0 & 0 & 59.8 & 29.5 & 9.23 & 0.06 & no values \\
\hline Anobothrus gracilis & 0 & 0 & 1.2 & 0.2 & 0 & 5.06 & 0.06 & no values \\
\hline Axinopsida orbiculata & 0 & 1.6 & 9.2 & 2.8 & 14.5 & 7.14 & 0.13 & no values \\
\hline Paroediceros lynceus & 0 & 0 & 0 & 0.8 & 4.0 & 6.87 & 0.14 & no values \\
\hline Haploops tubicola & 0.3 & 1.4 & 0.2 & 0 & 0 & 6.87 & 0.14 & no values \\
\hline
\end{tabular}




\section{Table 3(on next page)}

Species occurrence, likelihood of not finding a species, number of grabs taken and number of grabs required for finding a species calculated for the species present only at seep sites and only at C15 site 
1 Table 3. Species occurrence, likelihood of not finding a species, number of grabs taken and number of 2 grabs required for finding a species calculated for the species present only at seep sites and only at C15 3 site.

\begin{tabular}{|c|c|c|c|c|}
\hline \multirow[b]{2}{*}{ Species } & \multirow{2}{*}{$\begin{array}{l}\text { Species } \\
\text { occurrence }\end{array}$} & \multirow{2}{*}{$\begin{array}{l}\text { Likelihood of } \\
\text { not finding }\end{array}$} & \multicolumn{2}{|l|}{ Number of grabs } \\
\hline & & & $\begin{array}{l}\text { Required for } \\
\text { finding }(\alpha=0.99)\end{array}$ & Taken \\
\hline \multicolumn{5}{|c|}{ Species present at C15-seep $a, C 15$-seep $b$ and Oden and absent at C15 background and Control sites } \\
\hline Spiochaetopterus typicus ${ }^{1}$ & 0.62 & $4.79 \mathrm{E}-04$ & 4.8 & 8 \\
\hline Nephtys ciliata & 0.77 & 8.04E-06 & 3.1 & 8 \\
\hline Cossura longocirrata & 0.38 & 0.021 & 9.5 & 8 \\
\hline Anobothrus gracilis & 0.38 & 0.021 & 9.5 & 8 \\
\hline Oligobrachia sp. ${ }^{1}$ & 1 & 0 & 1 & 8 \\
\hline Axinopsida orbiculata ${ }^{1}$ & 0.77 & 8.04E-06 & 3.1 & 8 \\
\hline Paroediceros lynceus & 0.23 & 0.123 & 17.6 & 8 \\
\hline Pleusymtes pulchella ${ }^{1}$ & 0.53 & 0.002 & 6.0 & 8 \\
\hline \multicolumn{5}{|c|}{ Species present at Oden and absent at C15-seep $a$ and C15-seep $b$} \\
\hline Frigidalvania sp. ${ }^{1}$ & 0.57 & 0.006 & 5.4 & 6 \\
\hline Portlandia arctica & 0.43 & 0.035 & 8.2 & 6 \\
\hline Paroediceros lynceus & 0.43 & 0.035 & 8.2 & 6 \\
\hline
\end{tabular}

$4 \quad 1$ - Species absent not accidentally

5 


\section{Table 4 (on next page)}

Species richness, Pielou evenness, Hurlbert rarefaction for 100 individuals and ShannonWiener index calculated for trawl samples 
1 Table 4. Species richness, Pielou evenness, Hurlbert rarefaction for 100 individuals and Shannon-Wiener

2 index calculated for trawl samples.

\begin{tabular}{lcccc} 
Trawl & Species richness & Pielou evenness & ES (100) & Shannon-Wiener index \\
\hline C15 & 203 & 0.55 & 29.97 & 2.92 \\
Oden & 167 & 0.56 & 33.02 & 2.86 \\
\hline
\end{tabular}

3 


\section{Table 5 (on next page)}

Similarity percentage routine for trawl samples

Species with contribution $>0.5 \%$ are shown. Species more abundant at $C 15$ are marked with bold 
1 Table 5. Similarity percentage routine for trawl samples. Species with contribution $>0.5 \%$ are shown.

\begin{tabular}{|c|c|c|c|c|c|}
\hline \multirow{2}{*}{ Species } & \multicolumn{2}{|c|}{ Abundance (\%) } & \multirow{2}{*}{$\begin{array}{c}\text { Average } \\
\text { dissimilarity }\end{array}$} & \multirow{2}{*}{$\begin{array}{c}\text { Contribution, } \\
\%\end{array}$} & \multirow{2}{*}{$\begin{array}{c}\text { Cumulative, } \\
\%\end{array}$} \\
\hline & C15 & Oden & & & \\
\hline Frigidalvania sp. & 12.05 & 2.37 & 4.84 & 14.06 & 14.06 \\
\hline Ophiocten sericeum & 37.32 & 45.55 & 4.11 & 11.94 & 26.00 \\
\hline Yoldiella lenticula & 7.37 & 1.11 & 3.13 & 9.08 & 35.08 \\
\hline Yoldiella solidula & 7.82 & 10.89 & 1.54 & 4.46 & 39.55 \\
\hline Portlandia arctica & 2.56 & 0.15 & 1.21 & 3.51 & 43.05 \\
\hline Laona finmarchica & 1.60 & 0.00 & 0.80 & 2.32 & 45.38 \\
\hline Phascolion strombus & 1.95 & 0.36 & 0.80 & 2.31 & 47.69 \\
\hline Myriochele heeri & 0.42 & 1.82 & 0.70 & 2.03 & 49.72 \\
\hline Micronephthys minuta & 0.16 & 1.47 & 0.65 & 1.90 & 51.62 \\
\hline Craniella polyura & 1.30 & 0.00 & 0.65 & 1.88 & 53.50 \\
\hline Pholoe longa & 1.38 & 2.62 & 0.62 & 1.79 & 55.29 \\
\hline Munnopsis typica & 0.67 & 1.84 & 0.59 & 1.70 & 56.99 \\
\hline Scoletoma fragilis & 0.28 & 1.17 & 0.45 & 1.30 & 58.30 \\
\hline Paraoediceros lynceus & 1.80 & 0.92 & 0.44 & 1.28 & 59.58 \\
\hline Rostroculodes hanseni & 0.00 & 0.88 & 0.44 & 1.28 & 60.85 \\
\hline Nothria hyperborea & 0.10 & 0.90 & 0.40 & 1.16 & 62.01 \\
\hline Solariella obscura & 0.90 & 0.13 & 0.39 & 1.13 & 63.14 \\
\hline Tharyx sp. & 0.04 & 0.67 & 0.31 & 0.91 & 64.05 \\
\hline Axinopsida orbiculata & 0.00 & 0.61 & 0.30 & 0.88 & 64.93 \\
\hline Brada villosa & 0.66 & 0.06 & 0.30 & 0.86 & 65.79 \\
\hline Arrhis phyllonyx & 0.25 & 0.82 & 0.28 & 0.83 & 66.62 \\
\hline Terebellides aff. stroemii & 0.86 & 1.42 & 0.28 & 0.82 & 67.44 \\
\hline Similipecten & 0.68 & 0.15 & 0.27 & 0.78 & 68.22 \\
\hline Cylichna occulta & 0.74 & 0.21 & 0.27 & 0.77 & 68.99 \\
\hline Yoldiella frigida & 0.15 & 0.63 & 0.24 & 0.70 & 69.69 \\
\hline Cossura longocirrata & 0.04 & 0.52 & 0.24 & 0.70 & 70.39 \\
\hline Sabinea septemcarinata & 0.09 & 0.57 & 0.24 & 0.69 & 71.08 \\
\hline Nymphon hirtipes & 0.10 & 0.57 & 0.23 & 0.67 & 71.76 \\
\hline Cuspidaria glacialis & 0.80 & 0.38 & 0.21 & 0.61 & 72.37 \\
\hline Brada incrustata & 0.04 & 0.46 & 0.21 & 0.61 & 72.98 \\
\hline Lepidepecreum umbo & 0.42 & 0.02 & 0.20 & 0.58 & 73.56 \\
\hline Ephesiella abyssorum & 0.01 & 0.40 & 0.19 & 0.56 & 74.12 \\
\hline Nuculana pernula & 0.54 & 0.92 & 0.19 & 0.56 & 74.67 \\
\hline Rozinante fragilis & 0.51 & 0.15 & 0.18 & 0.53 & 75.20 \\
\hline Philine lima & 0.00 & 0.36 & 0.18 & 0.52 & 75.72 \\
\hline Pleusymtes pulchellus & 0.36 & 0.71 & 0.17 & 0.51 & 76.22 \\
\hline Owenia polaris & 0.07 & 0.42 & 0.17 & 0.50 & 76.72 \\
\hline
\end{tabular}

Species more abundant at $C 15$ are marked with bold 
Table 6(on next page)

List of filter-feeding taxa found in trawl samples 
1 Table 6. List of filter-feeding taxa found in trawl samples.

\begin{tabular}{|c|c|c|}
\hline \multirow{2}{*}{ Species } & \multicolumn{2}{|c|}{ Abundance (\%) } \\
\hline & C15 & ODEN \\
\hline \multicolumn{3}{|c|}{ Porifera } \\
\hline Sycon sp. & 0.13 & 0.06 \\
\hline Lycopodina lycopodium & 0.01 & - \\
\hline Mycale sp. & 0.01 & - \\
\hline Suberites domuncula & 0.16 & - \\
\hline Tentorium semisuberites & 0.01 & - \\
\hline Craniella polyura & 1.30 & - \\
\hline \multicolumn{3}{|c|}{ Cnidaria } \\
\hline Gersemia fruticosa & 0.03 & - \\
\hline Gersemia rubiformis & 0.01 & - \\
\hline Lucernaria bathyphila & 0.01 & - \\
\hline Lafoea dumosa & 0.06 & 0.15 \\
\hline Stegopoma plicatile & 0.01 & - \\
\hline Hydrozoa gen.sp. & 0.01 & - \\
\hline \multicolumn{3}{|c|}{ Polychaeta (Sabellidae + Spirorbidae) } \\
\hline Branchiomma arcticum & - & 0.02 \\
\hline Euchone analis & - & 0.04 \\
\hline Euchone papillosa & 0.17 & 0.02 \\
\hline Chone duneri & 0.03 & 0.13 \\
\hline Bushiella kofiadii & 0.01 & - \\
\hline Circeis spirillum & 0.04 & - \\
\hline \multicolumn{3}{|c|}{ Bryozoa } \\
\hline Alcyonidium disciforme & 0.12 & - \\
\hline Alcyonidium gelatinosum & 0.09 & - \\
\hline Crisia eburneodenticulata & 0.09 & 0.02 \\
\hline Defrancia lucernaria & 0.03 & - \\
\hline Tubulipora fruticosa & 0.03 & - \\
\hline Lichenopora sp. & 0.01 & - \\
\hline Carbasea carbasea & 0.04 & - \\
\hline Eucratea loricata & 0.12 & - \\
\hline Tricellaria gracilis & 0.01 & - \\
\hline Dendrobeania fruticosa & 0.04 & - \\
\hline Kinetoskias smitti & 0.06 & - \\
\hline Porella fragilis & 0.01 & - \\
\hline Cheilopora sincera & 0.12 & - \\
\hline Parasmittina jeffreysi & 0.03 & - \\
\hline Pseudoflustra birulai & 0.03 & - \\
\hline Pseudoflustra solida & 0.01 & - \\
\hline Ramphostomella bilaminata & 0.03 & - \\
\hline \multicolumn{3}{|c|}{ Tunicata } \\
\hline Didemnum albidum & 0.01 & 0.02 \\
\hline Ascidia sp. & 0.01 & - \\
\hline Synoicum pulmonaria & 0.01 & - \\
\hline
\end{tabular}

2 
Figure 1

Study area

Enlarged maps show sampling sites and corresponding stations. Detailed bathymetry is only available for $\mathrm{C} 15$ and Oden sites; white circles indicate previously recorded gas flares (Baranov et al., 2020). Dotted line at Oden site enclosed map shows the approximate perimeter of seeping area
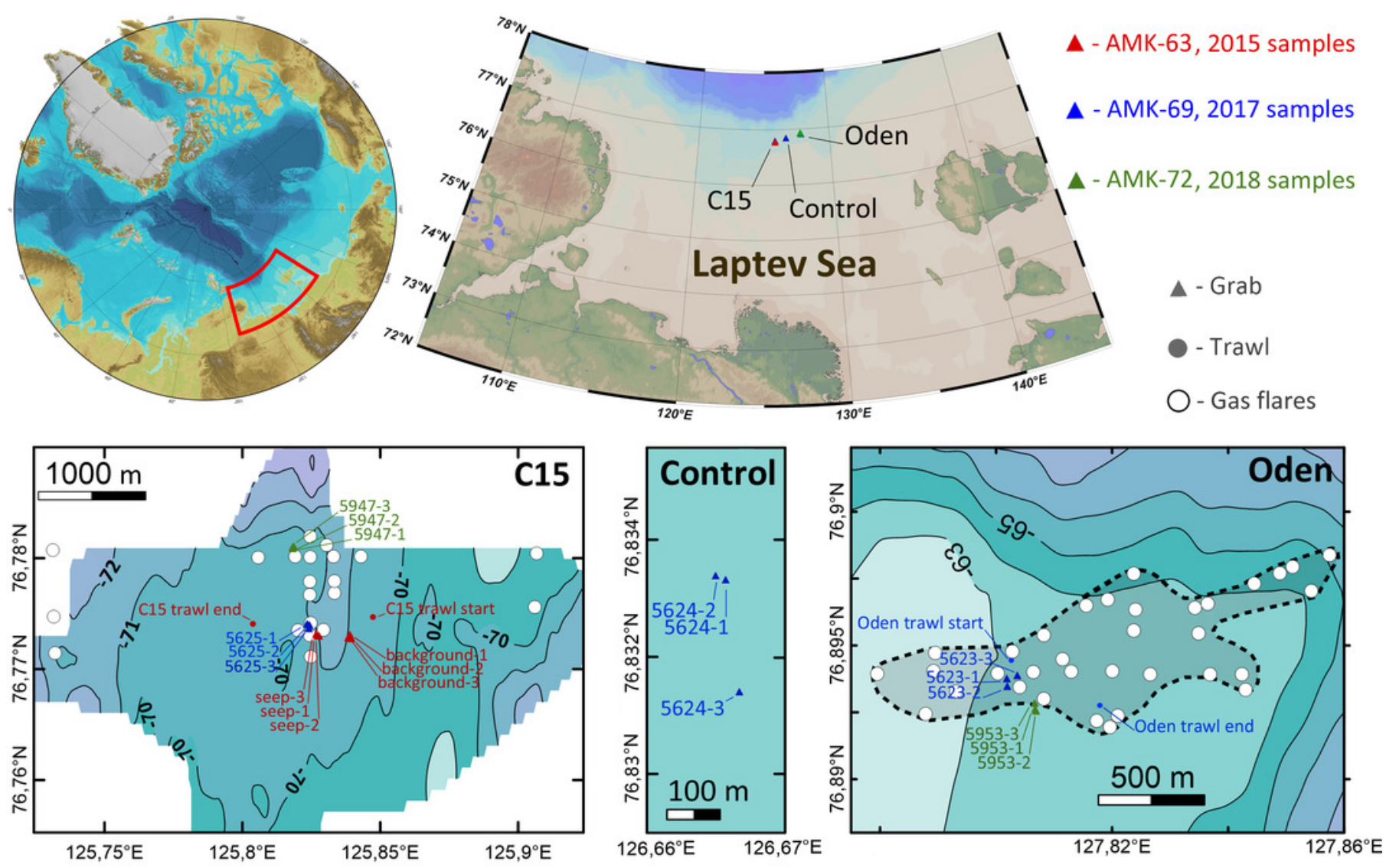
Figure 2

UNCTREE analysis with SIMPROF results $(A)$ and non-metric multidimensional scaling plot (B) of grab stations using the Bray-Curtis similarity index

Square root transformed biomass data are used. Samples and knots that were not significantly different at $p<0.05$ are connected with red dashed lines. Green lines indicate SIMPROF groups 


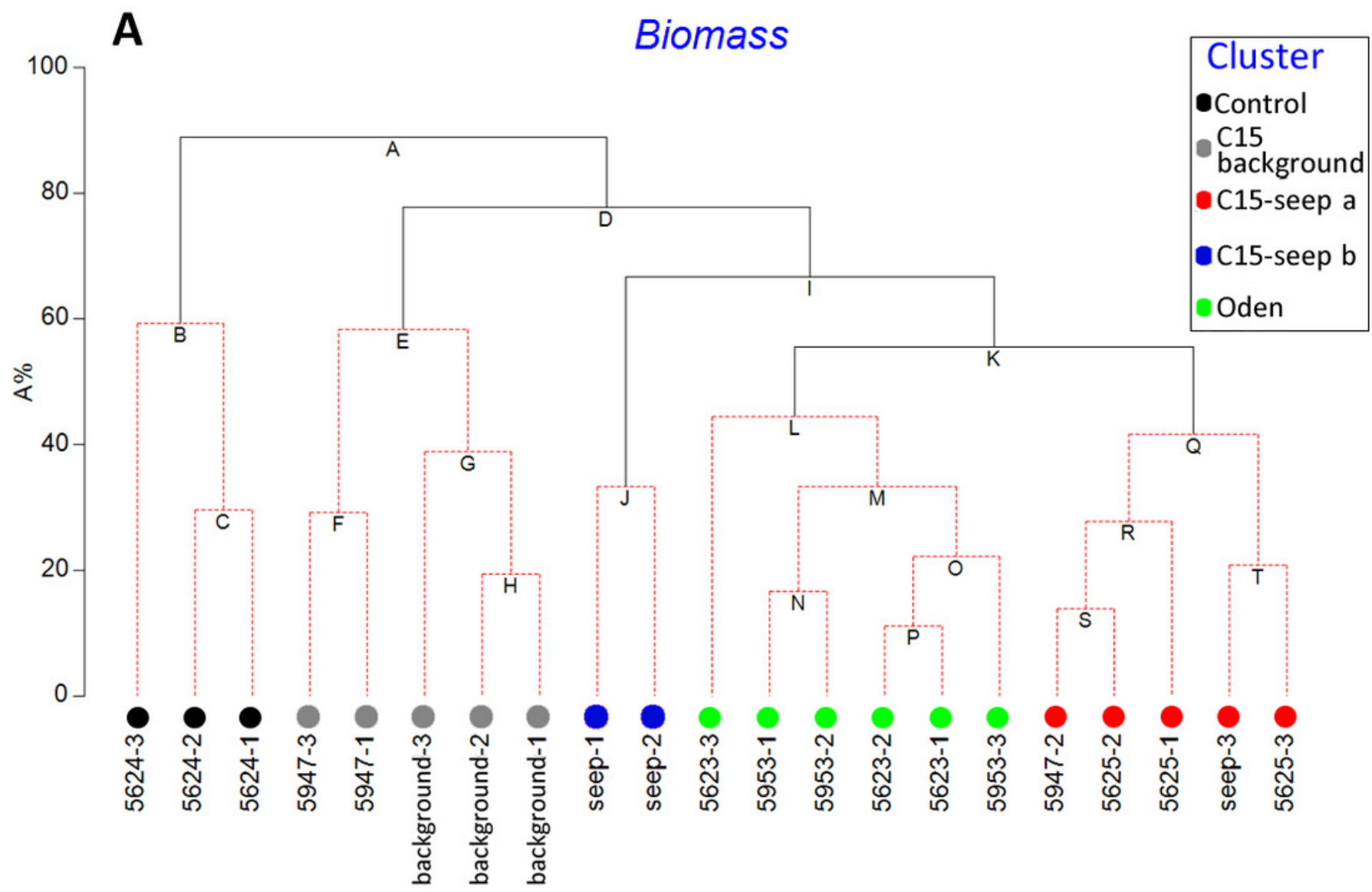

B

\section{Biomass}

Non-metric MDS

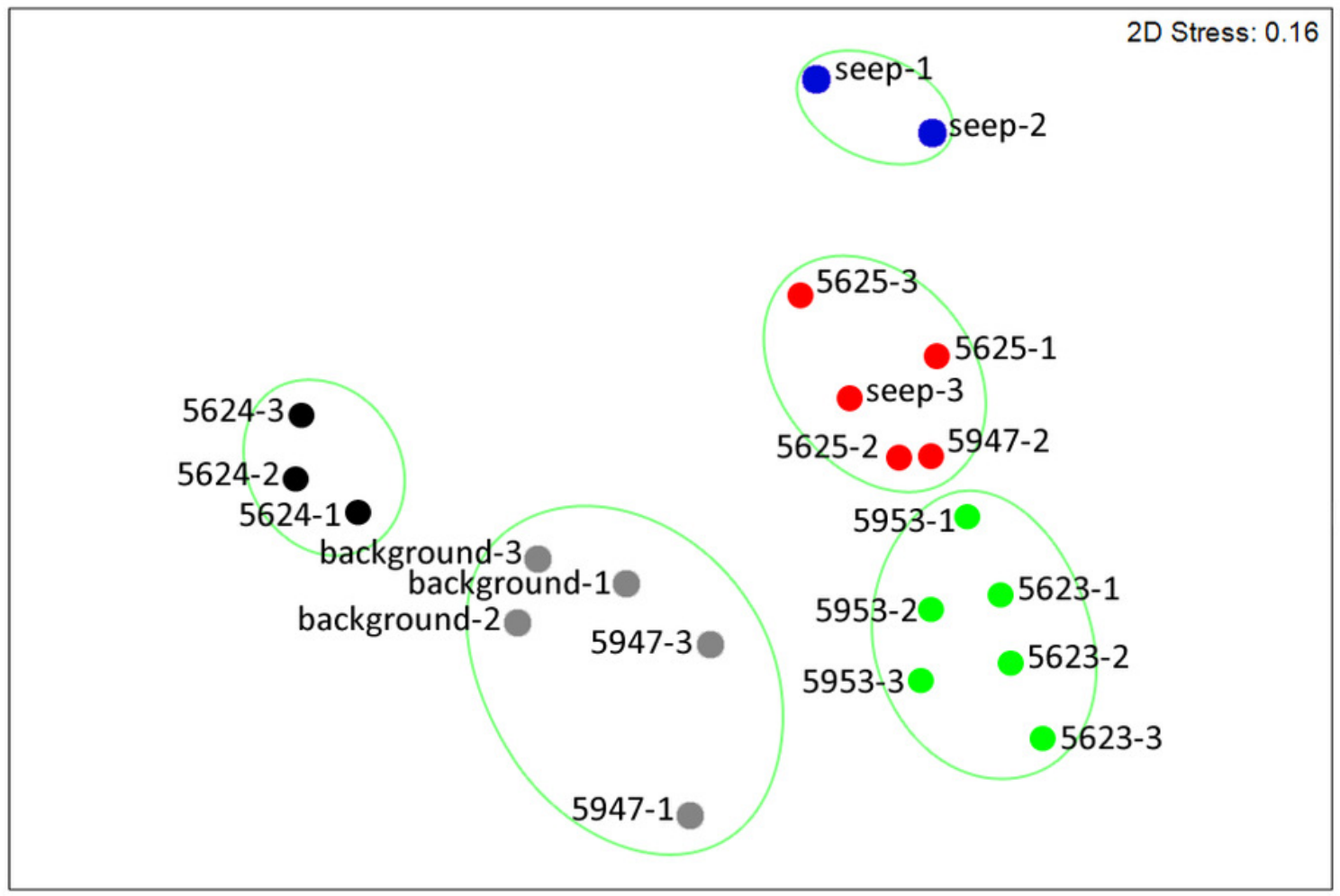

\begin{tabular}{|l|}
\hline Cluster \\
Control \\
C15 \\
background \\
c15-seep a \\
c15-seep b \\
Oden
\end{tabular}


Figure 3

The species-individuals accumulation curves for the station groups

Colors are the same as in Figure 2

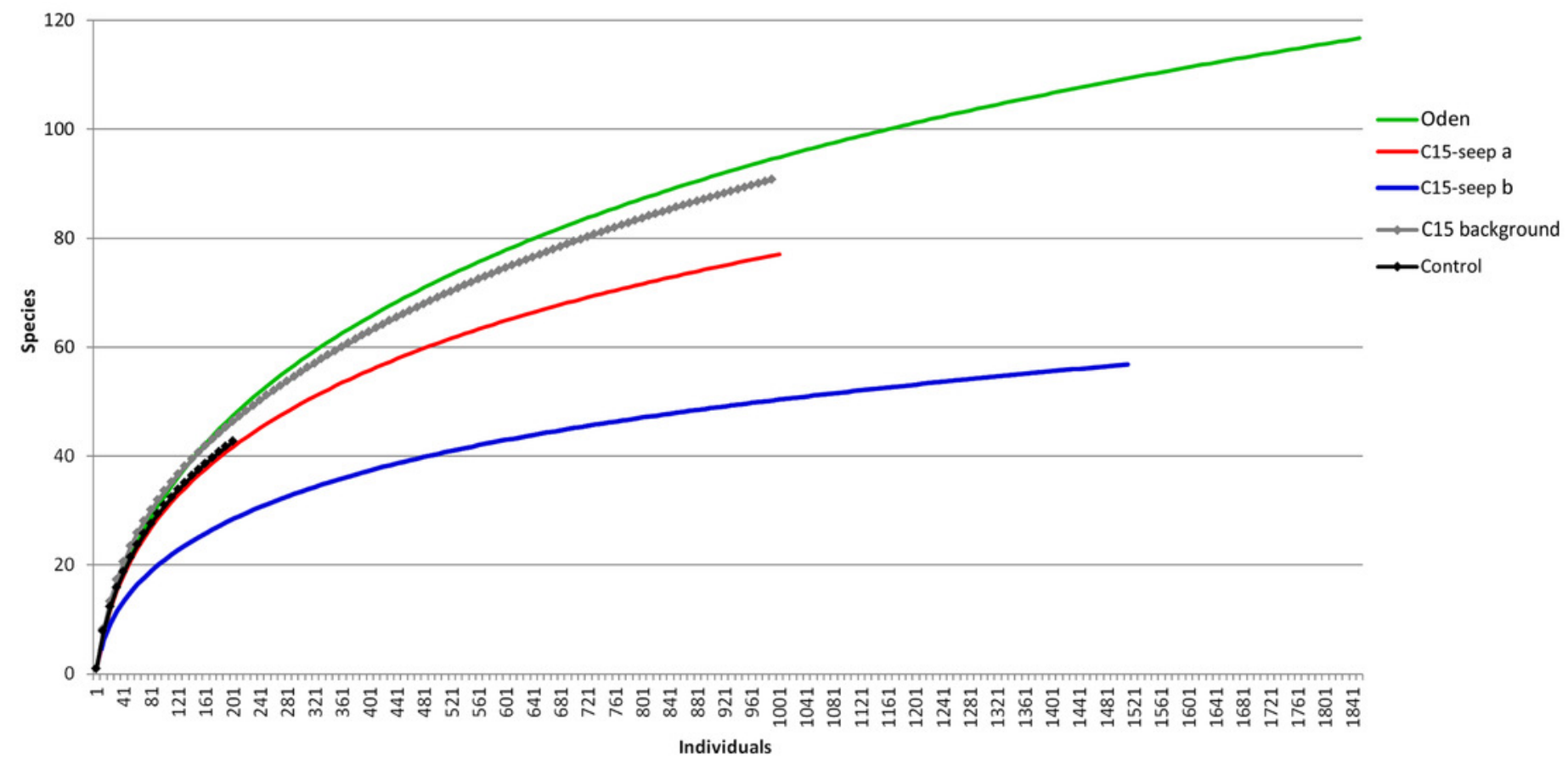




\section{Figure 4}

Univariative characteristics of identified clusters expressed in standard box plots Values of total density, biomass, species richness, Pielou evenness, Hurlbert rarefaction index and Shannon-Wiener index are shown. Each graph contains interquartile ranges (colored boxes), mean values (horizontal line inside each box) and minimum and maximum values (lines outside the boxes). Exact values of these characteristics are shown in Supplementary 3. Colors are the same as in Figure 2 and 3. 

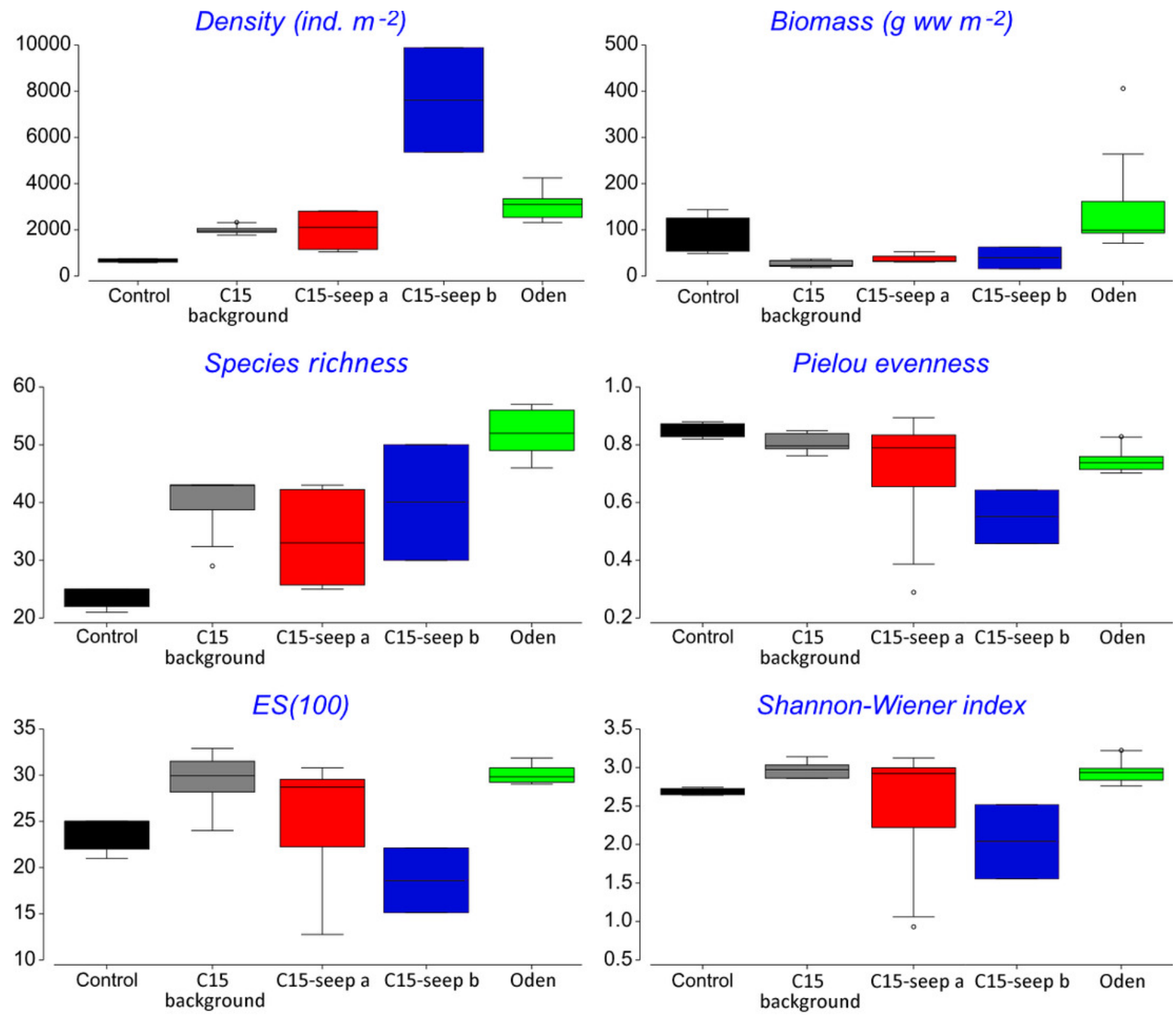
Figure 5

Shade plot of species square root transformed abundance (A) and biomass (B) at stations arranged by clusters

The species list is reduced to 20 most important taxa. Order of stations and colors the same as in Figure 2. Taxa grouped in clusters using UPGMA algorithm based on index of association 


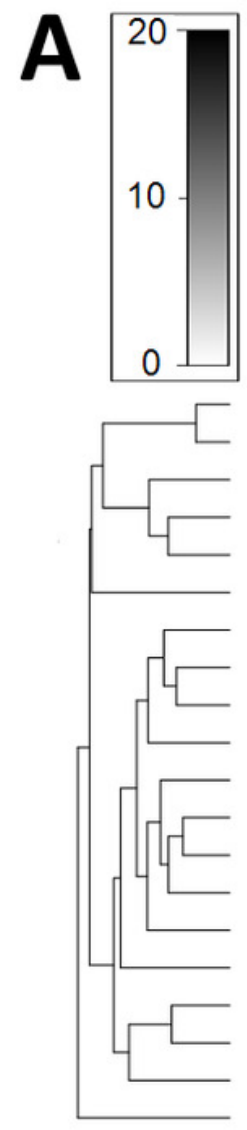

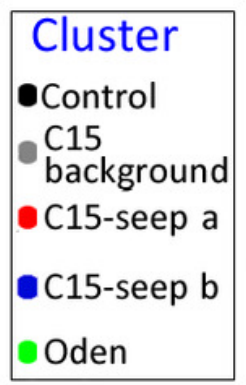

Cossura longocirrata Aceroides latipes

Lepthognathia gracilis

Ophryotrocha sp

Micronephthys minuta

Frigidalvania sp.

Scoloplos acutus

Pholoe longa

Ophiocten sericeum

Axinopsida orbiculata

Oligobrachia sp.

Myriochele heeri

Tharyx sp.

Scoletoma fragilis

Levinsenia gracilis

Owenia polaris

Yoldiella solidula

Yoldiella lenticula

Portlandia arctica

Paradulichia typica
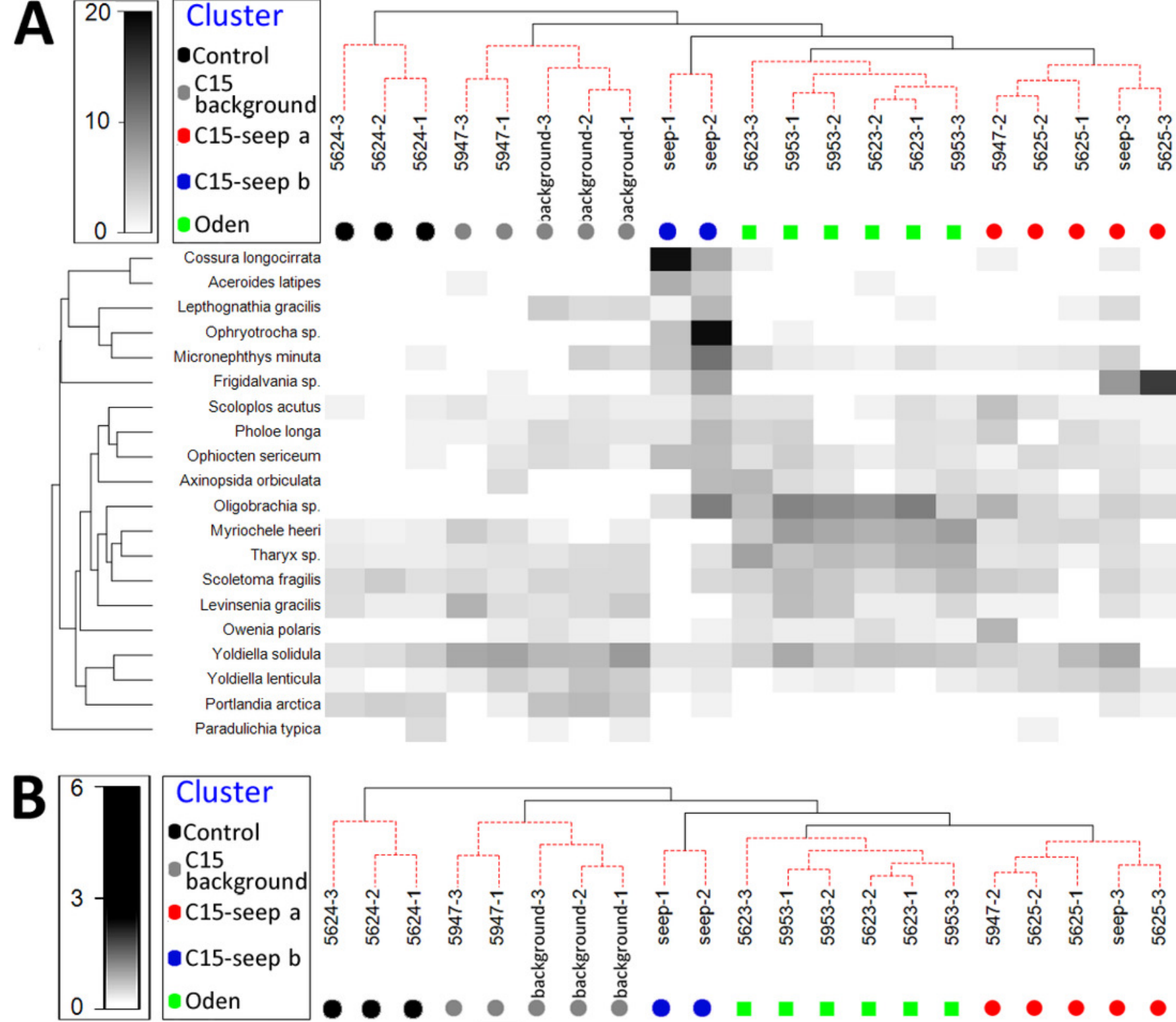

Periploma fragilis

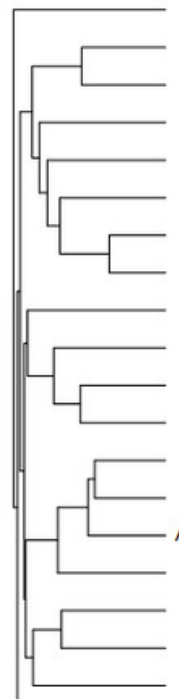

Brada incrustata

Nereis zonata

Golfingia margaritacea

Ampelisca eschrichtii

Laonice cirrata

Oligobrachia sp.

Nephthys ciliata

Frigidalvania sp.

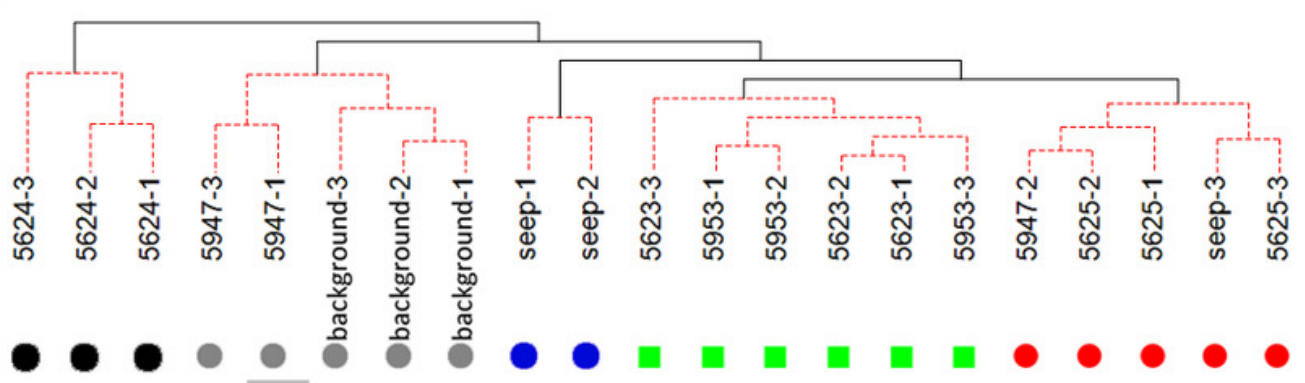
Arctolembos arcticus

Yoldiella lenticula

Nuculana pernula

Ctenodiscus crispatus

Macoma calcarea

Aglaophamus malmgreni

Portlandia arctica

Cossura longocirrata

Cistenides hyperborea

Lunatia pallida

Saduria sabini

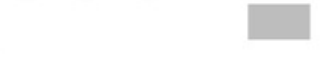


Figure 6

Species ranking for $\mathrm{C} 15$ and Oden trawl samples

The most numerous species are indicated. X-axis is logarithmic

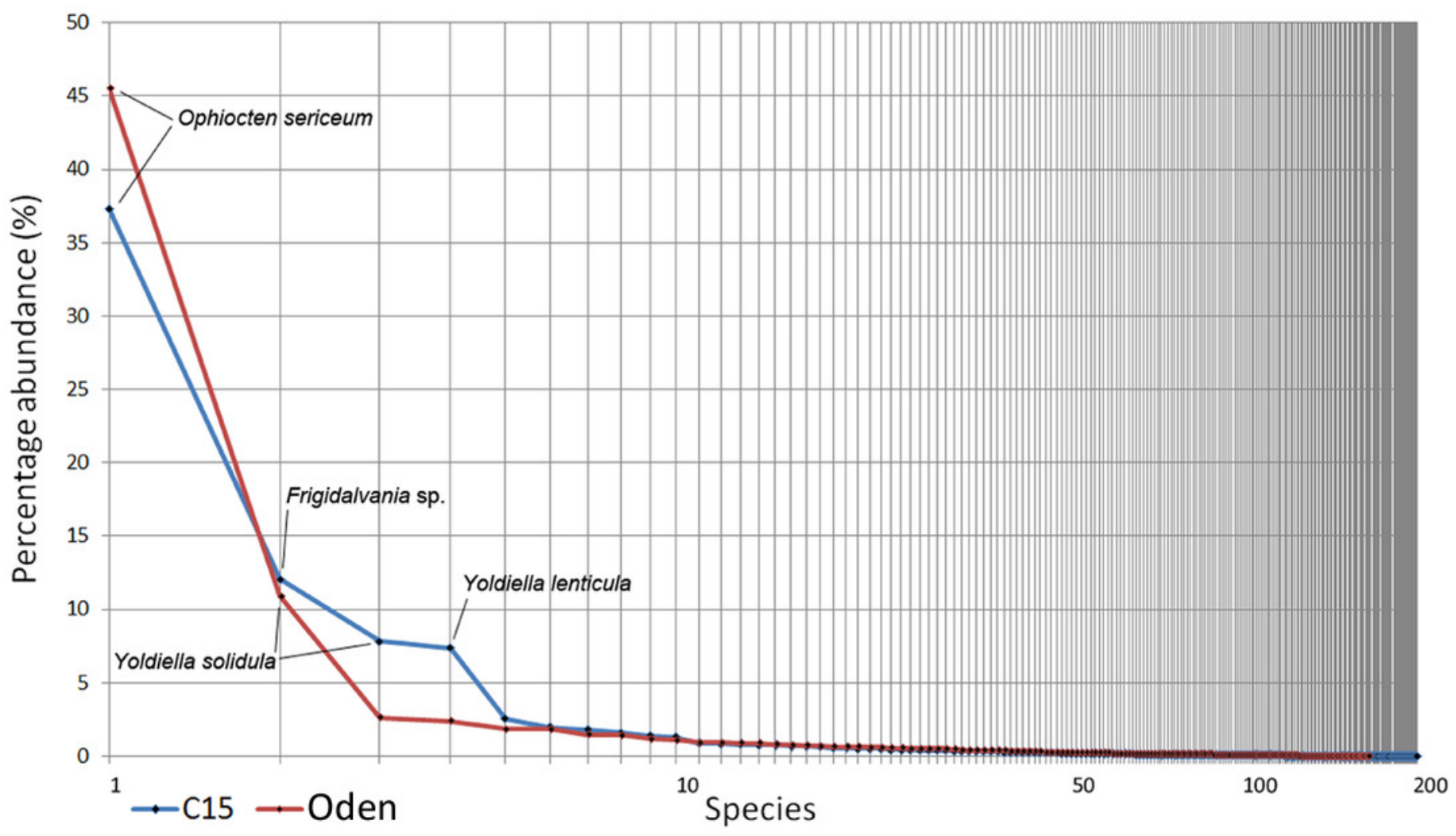




\section{Figure 7}

Taxa found only at seep stations

A - Oligobrachia sp. (left - tube with several fragments enlarged; center - complete specimen extracted from tube; right - anterior and posterior fragments of the specimen); B -

Frigidalvania sp.; C - Ophryotrocha sp. (upper left - several specimens, total view; upper right - anterior fragment; lower - enlarged parapodia); D - Axinopsida orbiculata. Photos by A. Vedenin and V. Kokarev 

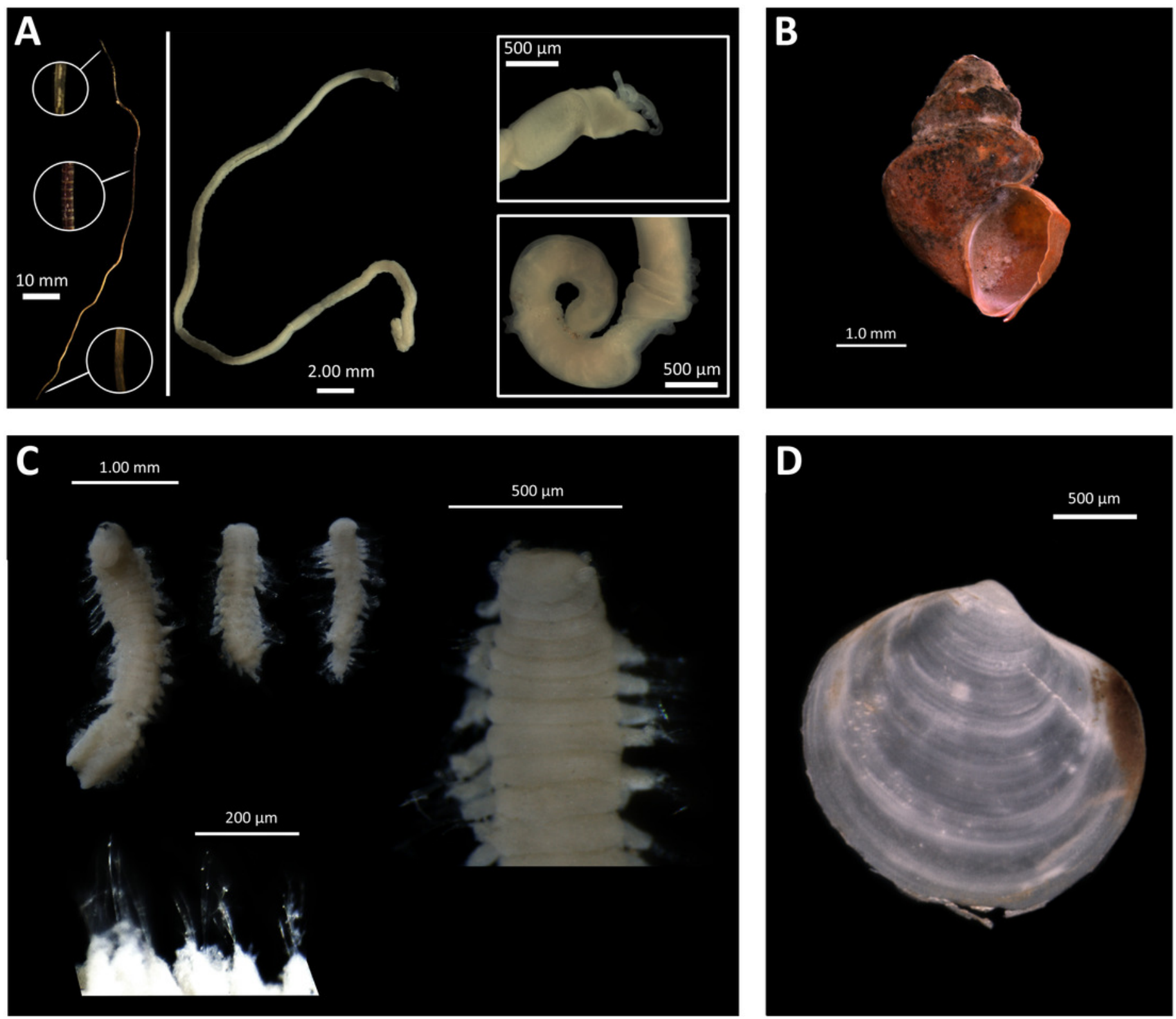